Article

\title{
Capabilities and Opportunities: Linking Knowledge Management Practices of Textile-Based SMEs on Sustainable Entrepreneurship and Organizational Performance in China
}

\author{
Aleem Ahmad Qader ${ }^{1}\left(\mathbb{D}\right.$, Jingwei Zhang ${ }^{1, * \mathbb{D}}$, Sheikh Farhan Ashraf ${ }^{2, * \mathbb{D}}$, Nausheen Syed ${ }^{3} \mathbb{D}$, \\ Khaoula Omhand ${ }^{4}$ (D) and Mehrab Nazir ${ }^{5}$ (D)
}

check for updates

Citation: Qader, A.A.; Zhang, J.; Ashraf, S.F.; Syed, N.; Omhand, K.; Nazir, M. Capabilities and

Opportunities: Linking Knowledge

Management Practices of

Textile-Based SMEs on Sustainable Entrepreneurship and Organizational Performance in China. Sustainability 2022, 14, 2219. https://doi.org/ $10.3390 /$ su14042219

Academic Editors:

Miltiadis Chalikias and

Michalis Skordoulis

Received: 28 December 2021

Accepted: 7 February 2022

Published: 15 February 2022

Publisher's Note: MDPI stays neutral with regard to jurisdictional claims in published maps and institutional affiliations.

Copyright: (C) 2022 by the authors. Licensee MDPI, Basel, Switzerland. This article is an open access article distributed under the terms and conditions of the Creative Commons Attribution (CC BY) license (https:// creativecommons.org/licenses/by/ $4.0 /)$.
1 Department of Business Administration, School of Economics and Management, Yanshan University, Qinhuangdao 066004, China; aleemroy@gmail.com

2 School of Management, Jiangsu University, 301 Xuefu Road, Jingkou District, Zhenjiang 212000, China

3 Department of Business Administration, Government College Women University, Faisalabad 38000, Pakistan; nausheen.dr@gmail.com

4 Wolverhampton Business School, University of Wolverhampton, Wolverhampton WV1 1LY, UK; k.omhand@wlv.ac.uk

5 School of Economics and Management, Jiangsu University of Science \& Technology, Zhenjiang 212000, China; mehrabnazir9@gmail.com

* Correspondence: ysuzjw@ysu.edu.cn (J.Z.); fhsheikh08@gmail.com (S.F.A.); Tel.: +86-186-5140-4595 (S.F.A.)

\begin{abstract}
Most researchers hold the role of dynamic capability (DC) as a key factor of achieving sustainable entrepreneurship performance (SEP) and Organizational Performance (OP) with the competitive advantage of knowledge management practices (KMPs). However, the effects of KMPs with SEP and OP are still under discussion. Moreover, the ambidexterity view, exploring the direct impact of KMPs mediated by dynamic capabilities (DC), gives evidence of sustainable entrepreneurship and organizational performance. Measuring the gathered data of 480 textile-based SME entrepreneurs and organizations through structural equation modeling, the study's finding shows that KMPs positively and significantly influence sustainable entrepreneurship and organizational performance. Furthermore, this study explores the partial mediation of dynamic capabilities among KMPs with SEP and organization performance. At the same time, opportunity recognition is a moderator that strengthens the relationship between DCs with sustainable entrepreneurship and organizational performance. The study is limited to male textile-based SMEs and can be enhanced by female entrepreneurs. Furthermore, this research contributes to entrepreneurship students by encouraging better research work in current and existing studies, and practically assists government and private policymakers and business practitioners to formulate better strategies for the sustainability and economic growth of a country.
\end{abstract}

Keywords: sustainable entrepreneurship performance; knowledge-sharing behavior; organizational performance; innovative capacity; SMEs; dynamic capability; opportunity recognition; China

\section{Introduction}

Globally, the worth for sustainable entrepreneurship has been increased due to its potential role in problem-solving and gaining competitive advantages. Due to the rapid change and development in the nature of business, a piece of knowledge is considered an important factor of success. In prior research, knowledge-sharing behavior and sustainable entrepreneurship investigate and resolve technical issues with sustainable practices [1,2] According to Zaim [3], knowledge is considered a tool for sustainable entrepreneurship and organizational performance. According to the author [1] outlined that sustainable entrepreneurship performance and competitive advantages are based on KMPs, such as knowledge-sharing behavior and innovative capacity, which build a positive relationship between entrepreneurial capabilities and sustainable entrepreneurship performance [4]. 
Sharing of knowledge is an important factor for achieving competitive advantages and organizational goals [5].

Small-medium enterprises (SMEs) can play a significant role in developing a country; mainly, they are considered a backbone in the economic development of developing countries [6]. Therefore, several entrepreneurial capabilities are essential to enhancing sustainable entrepreneurial performance (SEP) and achieving organizational development goals. SEP depends on more than just the willingness and commitment to becoming an entrepreneur [7]. Knowledge and capabilities are essential to becoming sustainable entrepreneurs [8].

KMPs assist small-medium entrepreneurs (SMEs) in sustainable entrepreneurship and organizational performance [9]. Researchers [10] explained KMPs as an explicit and important element in identifying and exploiting resources. Previous research focused on leadership practices with KMPs of sustainable entrepreneurship [11]. Valuable knowledge resources build an effective relationship among the creation and sharing of knowledge, innovativeness, and absorption of knowledge [12] with sustainable entrepreneurship and organizational performance [13]. The merger of these resources determines the KMPs, which are directly associated with organizational performance [14]. Organizational resources support in accomplishing market challenges and also enhance sustainable entrepreneurship and organizational performance [15]. Knowledge management practices help SME entrepreneurs to sustain and grow in the long run [9]. KMPs are directly associated with sustainable entrepreneurship performance; both SEP and knowledge management play a positive role in ensuring business growth [16].

The sharing of knowledge in an organization depends on the organizational atmosphere and the entrepreneurs' behavior, which is beneficial for sustainable performance. When KSB is restricted, the gaps ascend, creating performance hurdles [17]. The information about organizational schedules, depositories, repositories, and across organizational boundaries is gathered eventually with KSB are utilized for performance. The exchange of skills and experience within an organization is due to KSB, which increases firm performance [18]. Numerous studies suggest that SEP always supports the performance and market value of an organization [19]. However, several fundamentals, such as knowledgesharing behavior (KSB) and innovative capacity (IC), are directly related to the success of an entrepreneur [20].

The knowledge-based theory (KBT) creates and manages exclusive dynamic capabilities, which helps in sustainable entrepreneurship and organizational performance [4]. Prior research has examined the positive relations of KMPs with organizational [21] and sustainable entrepreneurship performance [22]. Therefore, organizations and entrepreneurs with effective KMPs achieve competitive advantages for organizational and sustainable entrepreneurship performance. The nature of sharing, acquiring, and applying knowledge enhances innovative capacity with performance. Modern research has outlined the interest of researchers in the KMPs of entrepreneurs and organizations in business studies, which assist in enhancing entrepreneurship and organizational performance [23].

Entrepreneurship performance is directly associated with knowledge management practices that enhance business and economic growth [22]. Prior studies suggested that knowledge management practices and entrepreneurship have a significant and positive relationship [24]. Knowledge management practices support the firm in creating, transferring, and applying information [4]. Sharing knowledge enhances the firm's strategic management and assists in developing the entrepreneurship process. The proper use of these resources gives competitive advantages to organizational and sustainable entrepreneurial performance. KMPs are not easy to change and are socially bonded but could assist in sustainable business growth. The value of knowledge has been exploited in organizations by focusing the business strategies and organizational performance.

In this regard, KMP can play a vital role due to its facilitating the sharing of information and dynamic capabilities from various time zones and geographical regions [25]. There is a growing need for approaches to improve KMP processes and procedures through 
the assessment of environmental, social, and economic consequences, given the increased need for sustainable entrepreneurial performance [26]. This study focuses on knowledge management practices contributing to many sustainability areas described in the literature. Knowledge-sharing behavior increases the tendency and understanding of the economic challenges in organizational culture, which entrepreneurs face during performance [27]. If there is no culture of sharing knowledge in the organization, with time, the gained information becomes old or useless once it Is developed, with no information shared, causing a decline in organizational performance [28]. The shared information in the firm's internal and external sources becomes informational, which benefits sustainable entrepreneurship performance. Knowledge-sharing behavior assists the entrepreneur in problem-solving, adopting and adapting new technology in organizational culture, invention, and creating core competencies for the entrepreneurship performance [29].

Previous research has stated that innovative capacity and innovation are also related to SEP [30]. The outcome of internal capacities with abilities that bring something different is known as IC which is directly correlated to the nature of SEP. The IC of an individual assists in entrepreneurship and organizational performance. Furthermore, the competitive advantages, overcome market strategies, and absorptive and innovative capacities enhance sustainable entrepreneurship performance [31]. IC categorizes abilities, assimilation, and knowledge utilization for SME performance. Entrepreneurs with IC can absorb and innovate the knowledge from competitors and apply it in the organization to enhance performance [31]. Researchers indicate that IC combines necessary abilities, understanding, and absorption of knowledge to integrate innovative knowledge for SEP [32], and practices managing the knowledge that can be used to achieve organizational goals. Therefore, it is important to measure the impact of such knowledge management practices on the SEP and OP of SMEs.

Dynamic capabilities with knowledge-sharing behavior in an organization can lead to rapid change with innovative capacity in SME performance [33]. The author [34] outlined an innovative capacity that helps with consistent improvement and upgrading of the capabilities of an entrepreneur. The capacity of capabilities assists in discovering, creating, and exploiting opportunities for entrepreneurship performance [35]. However, several studies have determined that the dynamic capabilities of an entrepreneur have a vital role in increasing performance, which can be further availed by using organizational resources to create, design, and modify an organization according to market challenges for organizational performance [36]. The innovative capacity increases the organizational capability to identify, learn, and observe external knowledge for innovation and performances [37]. Previous research [25] argued that dynamic capabilities help with managing innovative resources in an organization, and the performance of the entrepreneur is linked with dynamic capabilities.

Prior research [38] proved the direct and indirect impact of dynamic capabilities on firm performance. Several researchers found a positive relation between dynamic capability and organizational performance [39]. Numerous studies have explored the dynamic capability as a predictor variable to measure business and organizational performance; on the other hand, the relationship and impact of KMPs with sustainable entrepreneurship and organizational performance are still under-explored. Therefore, it is necessary to identify the direct effect of KMPs with DCs and the indirect effect of dynamic capability on sustainable entrepreneurship and organizational performance.

Furthermore, the concept of entrepreneurial opportunity recognition is to observe the market position, demand, and market value of a new product that affects SEP positively [26]. Previous research [40] claimed that "an opportunity may be the chance to meet a market need through a creative combination of resources to deliver superior value" [41]. Previous studies defined the concept of opportunity as identifying and availing the market opportunity through available resources that could improve the performance [42]. Researchers concluded that sources of discovering, evaluating, and exploiting information are opportunities [43] that enhance the entrepreneur's and firm's performance by the 
increase in capabilities [44]. Hence, several types of research have been conducted to explore entrepreneurship through KMPs with dynamic capabilities to get appropriate outcomes. Therefore, the DCs of SMEs in terms of KMPs play an important role in sustainable entrepreneurship and firm performance.

Sustainable entrepreneurship gives birth to startups, creativity, and market value [45]. This study aims to build a business venue using KSB and IC to develop sustainable entrepreneurship [46]. This research is based on knowledge-sharing behaviors (KSB) and innovative capability (IC) to enhance sustainable entrepreneurial performance [47]. Previous studies involved intentional models to understand sustainable entrepreneurship performance [48]. The core concept of developing this model is to build a relationship with KMPs in terms of textile-based SMEs. Achieving holistic business performance is associated with considering all aspects of sustainable development, particularly in the textile sector [49]. The primary objective of this study is to explore the relationship and impact of knowledge management practices on sustainability entrepreneurship performance through dynamic entrepreneurial capabilities.

The construct's knowledge-sharing behavior and innovative capacity positively impact SME performance (sustainable entrepreneurship and organizational) of China. The dynamic capabilities play a decisive role between constructs as mediators and opportunity recognition as a moderator between organizational performance and sustainable entrepreneurship performance. The researcher has an existing scale for this study because the validated scale is more convenient and reliable at verifying the constructs for the study, instead of developing new ones and consuming time. In the past, most studies were based on self-reported questionnaires and the standard method was used to collect data for research [6]. The researcher has a formative model for this study, applying SPSS and Smart-PLS to analyze the respondent's data [8]. To be specific, the study findings explore knowledge management practices, which influence sustainable entrepreneurship and organizational performance. Furthermore, this research explores the mediating and moderating role of dynamic capability and opportunity recognition via different analyses and develops hypotheses.

The study gap consists of different perspectives. The current study covers the existing gap in the scientific literature towards knowledge management practices (knowledgesharing behavior and innovative capacity) with organizational and sustainable entrepreneurship performance because no empirical study is available on this relationship in the China region. Secondly, the study also focuses on the dynamic capabilities (mediator) of entrepreneurs and organizations, and the textile-based SME sector is significantly increasing. Previous studies focused on and examined the influence of knowledge management practices on business performance [39,42], with innovation in the relationship as a mediator with organizational orientation and learning [50,51]. The concept of dynamic capabilities as a mediator among knowledge management practices with SME sustainable entrepreneurship and organizational performance is the motivation for this study.

On the other hand, the direct impact of dynamic capability on sustainable entrepreneurship and organizational performance is discussed in the literature [52]. Lastly, previous research neglected the relationship between dynamic capabilities and opportunity recognition with sustainable entrepreneurship and organizational performance [15]. Opportunity recognition recognizes an opportunity/idea, and capabilities assist in availing the market opportunities for better performance for businesses, entrepreneurs, and organizations. Therefore, the conducted study examines the concept of opportunity recognition as a moderator in the relationship between dynamic capabilities, sustainable entrepreneurship, and organizational performance.

\section{Theoretical Justifications and Hypothesis Development}

The research model is based on fundamental theories and existing studies, including the antecedents to Schumpeter's entrepreneurship theory [8]. Sustainable entrepreneurship performance is supported by the entrepreneurship theory (ET) for organizational 
resources, capabilities, and capacities. Meanwhile, the "resource-based theory" also accentuates the role of innovative capacity, which is directly associated with enhancing organizational performance [53]. It is applied to acquire and examine the organizational capacities, capabilities, and management strategies to achieve competitive advantages [54] and internal and external assets with available resources for sustainable performance [55]. Opportunity recognition gives entrepreneurs a chance to generate ideas and develop products [56] for better SEP. As the knowledge-based theory (KBT) is applied, the organizational and entrepreneurial skills are enhanced, which leads to better entrepreneurship performance [57]. In addition, entrepreneurs and firms with more knowledge management practices efficiently achieve and maintain business sustainability [34]. Many researchers have demonstrated that sharing, absorbing, and applying knowledge tends to improve capacities, capabilities, and sustainable entrepreneurship performance [1]. Therefore, to develop the holistic research model, the abovementioned theories were included to meet the research objectives.

Latest research [58] argued that innovative capacity relies on organizational capital and human resources, including the organizational infrastructure of work environments. Here, the innovative organizational infrastructure also means the elements that increase the innovative capacity in entrepreneurship performance [59]. The innovation organizational commercialization process positively affects a firm's performance [60]. If the overall population is recommended to become entrepreneurs at a mature age, it raises concerns affecting business creation and innovative capacity. The word "self-employment" is used as a synonym for entrepreneurship, and if the self-employed age become high, the rate of self-employment also becomes high. Still, the innovative capacity of entrepreneurs will fall.

Researcher [22] argued that DCs are the combinations of activities and designed structure that help in learning and enhancing the daily routine performance of entrepreneurs [61]. Entrepreneurial and organizational capabilities assist in managing available resources in performance. Therefore, firms need to focus on individuals' dynamic interpersonal capabilities [20]. Entrepreneurs consider dynamic capability a major asset for organizations [62]. Entrepreneurship performance can be measured through the rate of accepting and implementing innovation in an organization [63]. Furthermore, sustainable entrepreneurship is also concerned with decision-making, risk-taking research, development, product invention, and dynamic capabilities.

The author [17] argued that "market interaction and entrepreneurs' life experiences related to the market, industrial knowledge, and resources should be considered for opportunity recognition." The researchers proposed that an opportunity may have an impression of vaguely distinct market needs, which means that potential consumers may or may not have the capability to articulate their demands and interests. Identifying a customer's needs might lead to a prompt appearance of opportunity recognition, resulting from better organizational performance [31]. In addition, the researchers suggested that market potential influences opportunity recognition in product development. Therefore, entrepreneurship is related to the process of evaluation, discovery, exploration, sources, and recognition of opportunities that highly influence entrepreneurship and organizational performance.

The onerous task was to identify and select the appropriate research method for the study. There is no single method or knowledge to describe the whole study methodology. At the minimum, one research method should be used at every stage to analyze and formulate the valuable information and data of the study. The research design describes the procedure for collecting and analyzing data, and the quantitative random sampling technique was selected for this study. The study confirms how the researcher defined and practically solved the research problems and makes them as clear as possible. This study evaluates the direct relationships of seven constructs from the proposed research model, as well as the direct, indirect, mediation, and moderation effects. 


\subsection{Knowledge Sharing Behavior, Dynamic Capability, and Sustainable Entrepreneurship Performance}

Thomas Begley and David Boyd came up with five concepts for entrepreneurial performance, such as control/hold, risk-taker, problem solver, knowledge-sharing behavior, and time management [64]. Knowledge-sharing behavior and decision-making power make an entrepreneur active in market knowledge and society, with dynamic capabilities and raising entrepreneurial performance. It is usually based on four fundamentals: faceto-face sharing (knowledge-sharing behavior), value (power), poise (confidence), and patriarchy. Knowledge-sharing behavior of an individual is not enough for the organization; innovative and absorptive capacity are also needed. There is a strong relationship between entrepreneurship and knowledge management [65]. Still, knowledge management is not enough to enhance entrepreneurial performance. Knowledge-sharing behavior with dynamic capabilities exists in an entrepreneur enhance the performance [66]. Some factors are mandatory for entrepreneurial performance, such as knowledge-sharing behavior, innovative capacity, valid strategies, and action plans with dynamic capability [36].

Therefore, in dynamic environments of an organization, knowledge-sharing behavior and one's own valuable resources develop the dynamic capability for competitive advantages in entrepreneurial performance [67]. The researchers [68] argue that knowledgesharing behavior helps the dynamic capability to innovate new products, engage the entrepreneur in absorbing the change, show a willingness for competitive advantages, and raise positive change in entrepreneurial performance. The researchers argue that entrepreneurial performance raises dynamic capability due to knowledge-sharing behavior and available resources [69]. The increase in knowledge-sharing behavior makes the dynamic capability stronger for entrepreneurial performance [42].

Hypothesis 1a (H1a). Knowledge-sharing behavior has a positive influence on sustainable entrepreneurship performance.

Hypothesis 1b (H1b). Knowledge-sharing behavior has a positive influence on dynamic capability.

Hypothesis 1c (H1c). Dynamic capability mediates the relationship between knowledge-sharing behavior and sustainable entrepreneurship performance.

\subsection{Innovative Capacity, Dynamic Capability, and Sustainable Entrepreneurship Performance}

The study mentioned that innovation comes from using different factors such as sharing and absorbing knowledge, whereas dynamic capabilities enhance innovative capacity for entrepreneurship performance [41]. The researcher [70] stated that absorbing external knowledge brings innovation, and innovative capacity causes an advancement in entrepreneurship performance. Different scholars mentioned that absorbing external knowledge prepares the entrepreneur for innovative capacity. When innovative capacity becomes higher, it gives an edge to entrepreneurship performance by using dynamic capabilities [71]. Moreover, for the successful use of innovative capacity, an entrepreneur uses dynamic capabilities to absorb innovation for entrepreneurship performance [72]. To absorb the organizational innovative resources, dynamic capabilities enhance the innovative capacity, differentiating the entrepreneurs across the market due to dynamic capabilities [73].

The dynamic capability is to share, acquire, adapt, and absorb internal and external knowledge that enhances innovative capacity in an entrepreneur [74]. The purpose of dynamic capability is to explore rare and valuable resources for entrepreneurship performance in an organization. The researchers argue that dynamic capability is an important factor for the entrepreneur, who acquires and sustains competitive advantages and assists in managing innovative capacity, according to organizational and entrepreneurial performance [75]. The study revealed that capacity and dynamic capability correlate significantly in entrepreneurial performance [45]. This research explored the effect of innovative capacity 
on entrepreneurship performance and the role of dynamic capability as a mediator between innovative capacity and sustainable entrepreneurship performance [76]. Therefore, the following hypothesis is proposed:

Hypothesis 2a (H2a). Innovative capacity has a positive influence on sustainable entrepreneurship performance.

Hypothesis $\mathbf{2 b} \mathbf{( H 2 b ) . ~ I n n o v a t i v e ~ c a p a c i t y ~ h a s ~ a ~ p o s i t i v e ~ i m p a c t ~ o n ~ d y n a m i c ~ c a p a b i l i t y . ~}$

Hypothesis 2c (H2c). Dynamic capability mediates the relationship between innovative capacity and sustainable entrepreneurship performance.

\subsection{Knowledge-Sharing Behavior, Dynamic Capability, and Organizational Performance}

The less valuable but effective organizational capabilities should be shared for organizational performance [46]. In the view of Teece [77], dynamic capability covers all capabilities such as sensing, reconfiguring, and seizing capability in organizational performance. Dynamic capabilities assist in transforming and managing critical situations during the phase of organizational performance. Knowledge always plays a vital role in gaining competitive performance advantages and retaining sustainability in the dynamic economy [78]. Dynamic capability guides organizational performance on transferring expertise and knowledge from experts to novices. Dynamic capabilities guide in utilizing the valuable resources for organizational performance [79]. In the context of dynamic capability, it helps to innovate a new product and engage the organization to accept, create, and show its willingness for competitive advantages through knowledge-sharing behavior for organizational performance [80].

Surprisingly, there is less research that has tested the relationship between organizational performance and knowledge-sharing behavior empirically; therefore, such relationships are not well articulated, especially in the context of the dynamic capabilities of textile-based entrepreneurs. There is a considerable role of dynamic capability as a mediator between organizational performance and knowledge-sharing behavior in the SME sector [1]. Knowledge-sharing is an incentive for organizational performance and increases resources, with dynamic capabilities playing a considerable role as a mediator to innovate new products [78]. The excessive use of dynamic organizational capabilities based on the information depends on the knowledge-sharing in the organization, which leads the organization to better performance. Therefore, the following hypothesis is proposed:

Hypothesis 3a (H3a). Knowledge-sharing behavior has a positive influence on organizational performance.

Hypothesis $3 \mathbf{b} \mathbf{( H 3 b ) . ~ D y n a m i c ~ c a p a b i l i t y ~ m e d i a t e s ~ t h e ~ r e l a t i o n s h i p ~ b e t w e e n ~ k n o w l e d g e - s h a r i n g ~}$ behavior and organizational performance.

\subsection{Innovative Capacity, Dynamic Capability, and Organizational Performance}

The researchers discovered that innovative capacity also raises the energy level of an organization, which positively influences performance. In an organization, the dynamic capabilities permit the resources for organizational performance [81]. The organizations with more innovative capacity are likely to complete objectives with such corresponding interactions [68], such as analyzing the cooperation, possession, social relationships, and technical and human resources with dynamic capabilities to determine the innovative capacity in an organization [37] and following different actions with dynamic capabilities that never impede risk-taking attitudes for organizational performance.

Moreover, the organizations with higher innovative capacity are probably more prone to innovative ideas and better positioned to recognize market opportunities to bring out new products earlier than competitors for organizational performance [82]. Secondly, connecting new business with other firms makes it easier for an organization with higher 
innovative capacity to accumulate the resources required for new items to facilitate the market with better organizational performance [83]. Innovative capacity with dynamic capabilities impacts the basic and simple characteristics of the organization in organizational performance, and it is a fact that dynamic capability influences the relationship between innovative capacity and organizational performance. Consequently, organizational performance can be measured with several parameters, such as financial matters and monetary actions, innovative capacity, and dynamic capabilities [51].

The dynamic power and dynamic ability of a firm with market techniques upgrade inventive capacity, which enhances the process and mechanical advancement performance [60]. The scholars propose that achieving, creating, appropriating, and offering assistance with dynamic capabilities increase the firm's performance [84]. The formation of a firm based on innovative capacity is central to an intricate chain; the dynamic capabilities shape the value series in an organization and enhance organizational performance. The interchange and utilization of new or former firm resources with innovative capacity increases organizational performance [85]. Therefore, the following hypothesis is proposed:

Hypothesis $4 \mathbf{a} \mathbf{( H 4 a )}$. Innovative capacity has a positive influence on organizational performance.

Hypothesis $\mathbf{4 b}(\mathbf{H} 4 \mathbf{b})$. Dynamic capability mediates the relationship between innovative capacity and organizational performance.

\subsection{Dynamic Capability, Sustainable Entrepreneurship, and Organizational Performance}

Dynamic capabilities play a role in designing and restructuring the vital environmental changes associated with entrepreneurship performance. In high-tech firms, the dynamic capability of an entrepreneur is the most reliable and sound source to advantage of, which is ultimately beneficial for entrepreneurship performance [22]. Moreover, dynamic capability plays a mediating role between entrepreneurial resources and performance. The resourcebased theory also explores the dynamic capability of an entrepreneur for business and entrepreneurship performance. The dynamic capability assists in facing new challenges and catching new opportunities from the market and helps maintain and develop sustainable entrepreneurship performance [86]. Nowadays, the dynamic capabilities of an entrepreneur are the most evolving topic for many researchers, especially in the SME sector. Dynamic capability involves understanding, investigating, and analyzing the entrepreneurial level of competencies for entrepreneurship performance [44]. Prior studies endorsed that the dynamic capability of an entrepreneur enhances resource capacity and entrepreneurship performance in an organization.

Dynamic capability enhances organizational capacities such as innovative capacity, market orientation, market differentiation, low-cost policy, and return on investment, sales, profit, assets, and organizational performance. The representative-driven power, with dynamic capacity in an association, plays a critical effect on upper hands and hierarchical execution [64]. Dynamic capabilities overcome the challenges and assists in achieving the competitive advantages [65]; additionally, they limit the normal contenders' activities with potential authoritative execution of the promotional section and work with businesspeople and associations via thought creation.

Hypothesis 5a (H5a). Dynamic capability has a positive and significant impact on sustainable entrepreneurship performance.

Hypothesis $\mathbf{5 b} \mathbf{b} \mathbf{H} \mathbf{5 b})$. Dynamic capability has a positive and significant impact on organizational performance. 


\subsection{Opportunity Recognition, Dynamic Capability, and Sustainable Entrepreneurship Performance}

The theory of OR proposes that the cognition of several entrepreneurs results in different ways of entrepreneurial processes and performance [87]. Meanwhile, the study by Hasan [20] explored the role of opportunity recognition with sustainable entrepreneurship performance as a mediator. Furthermore, existing studies that explored entrepreneurs' self-made strategies provided significant results in the OR process. However, due to less focus in prior research, this research incorporates the opportunity to evaluate the effect of OR between DC and SEP as a moderator. In this manner, the advantages are significant for business visionaries and affect organizations, except if dynamic capabilities not applied [88]. Dynamic capabilities are the best source of competitive advantages. The opportunity covers the best resources from the market to achieve competitive and sustainable entrepreneurship performance [89].

Hypothesis 6a (H6a). Opportunity recognition has a positive influence on sustainable entrepreneurship performance.

Hypothesis $\mathbf{6 b} \mathbf{( H 6 b ) . ~ O p p o r t u n i t y ~ r e c o g n i t i o n ~ a c t s ~ a s ~ a ~ m o d e r a t o r ~ f o r ~ t h e ~ r e l a t i o n s h i p ~ b e t w e e n ~}$ $D C$ and SEP (an increase in OR will lead to strengthening the relationship between DC and SEP).

\subsection{Opportunity Recognition, Dynamic Capability, and Organizational Performance}

The opportunity for authoritative execution, a positive business vision, unique abilities, market information, and situating administrations provides more freedom to secure the market to develop and make due [90]. Organizations with dynamic capabilities perform better than those without; meanwhile, opportunity recognition improves product development and organizational performance [91]. Prior studies focused less on SME studies related to dynamic organizational capabilities and drivers in smaller organizations. The researcher in [92] outlined the importance of dynamic capabilities in SMEs for better competitive advantages. The main problem for small-medium enterprises is recognizing the opportunities and the importance of dynamic organizational capabilities for organizational performance. Consequently, this review proposes that better chance acknowledgment would prompt higher authoritative execution. The accompanying hypothesis was thus formed:

Hypothesis 7a (H7a). OR positively affects organizational performance.

Hypothesis $\mathbf{7 b} \mathbf{( H 7 b ) . ~ O R ~ m o d e r a t e s ~ b e t w e e n ~ D C ~ a n d ~ O P . ~}$

\section{Conceptual Framework}

Figure 1 shows the variable studied in a conceptual model. The study's purpose was to examine the impact of KMPs (knowledge-sharing behavior) and innovative capacity on sustainable entrepreneurship and organizational performance. Moreover, the study also examined the role of DC and OR as mediators and moderators between KMPs, DCs, SEP, and OP. 


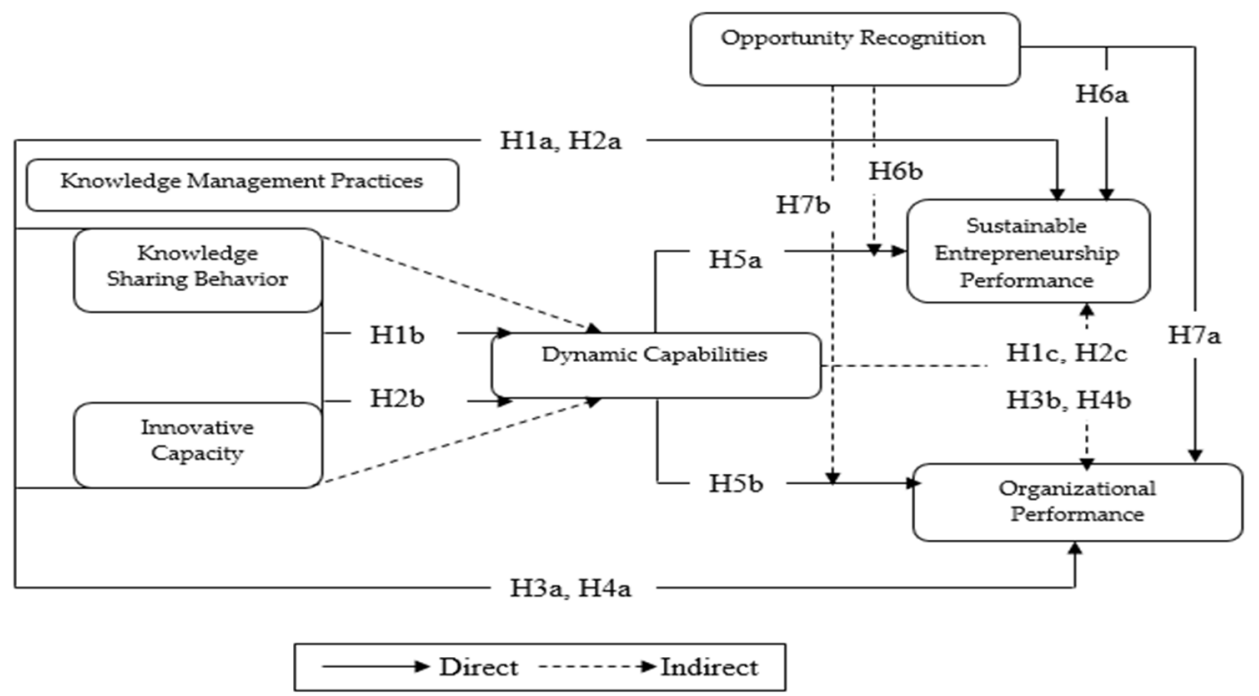

Figure 1. Research framework.

\section{Materials and Method}

This research used a quantitative approach. The numerical data were used to measure the study's variables in the problem statement and collect data from a large population. The quantitative survey analyzed and explored the research objectives, validity, and reliability of the questionnaire. The researchers outlined that the quantitative research approach is an authentic way to evaluate the relationship among variables [93]. The current study applied a deductive approach to test the proposed hypotheses developed based on the theory [94], and the survey method was applied to examine the hypotheses. The data for this study were collected from respondents using non-probability convenience sampling. The convenience sampling technique was applied to textile-based SMEs of China with the cross-sectional study [95].

The cross-sectional approach was used in the study and a total of 750 questionnaires were distributed in January 2021 among SME entrepreneurs; in return, 650 responses were received and the data collection process was completed in August 2021. The last 480 responses were finalized, and 170 were discarded due to improper and missing information. There is no specific list for SMEs, and the researchers completed the data collection process in different steps due to the busy schedules of the entrepreneurs. The respondents were approached through email and physically for different cities' listed SMEs (Zhenjiang, Changshu, Hebei, Tianjin, and Wuxi).

Although China is still very involved in the SME sector, textile-based SMEs are less examined. This study was also conducted to examine how corporate-sector firms work with KMPs and what improvement is needed in SME sectors with KM practices to attain long-term entrepreneurial success. Meanwhile, as the fundamental source of knowledge is the acquisition and application of information, which leads to sustainable performance, it may help to understand the specific status of KM practices and provide practical consequences to other non-certified businesses in China. Furthermore, they are better equipped with appropriate information and, at the same time, play an essential role in knowledge transmission among diverse departments. In addition, the researcher also developed trust in the respondents regarding their personal information, which will be kept secret. This research is purely for educational and research purposes.

The sample size selection is also a crucial part of the research methodology; an inadequate sample size could lead to the study's failure or may not be truly representative of the population. A large sample size of data can create a problem for researchers when collecting and managing data, which causes extra time consumption, which may take away from the actual purpose of sampling [96]. The questionnaire was initially drafted in English, but it was intended for use in Chinese, the official language of China. Therefore, the English 
questionnaire was translated into simplified and traditional Chinese by the researchers and professional native translators, working independently to ensure consistency and to make it easier for the respondents to comprehend [95]. Moreover, the researchers tried to encourage female entrepreneurs to participate in the survey; however, they mostly refused to participate. Therefore, this study is based on male SME entrepreneurs. The partial least square (PLS)-structural equation modeling (SEM) technique analyzed the proposed research model using Smart-PLS v3. Smart-PLS. It is a powerful tool used to test mediation-moderation models and works with multivariate and normal distributions simultaneously [97]. Additionally, it helps measure the validity and reliability of studies.

\subsection{Demographics of Respondents}

Table 1 describes the sample statistic frequency distribution of the targeted respondents. The sample statistics include age, qualification, the business sector of the entrepreneur, and business tenure. The results show that most of the respondents fell in the age group of $40-46$ years old $(27.50 \%)$, whereas $26.46 \%$ of the respondents were above 45 years, $23.54 \%$ were young entrepreneurs between $33-39$, and $22.50 \%$ were quite youngbelow 32 and above 18 years old. Young entrepreneurs with high qualifications and professional education were fewer in number, whereas $32.50 \%$ had a middle school and $27.50 \%$ had a high school certificate. During the data collection phase, we discovered that most senior entrepreneurs did not have higher education and ran successful enterprises. This may have been due to their leadership abilities, financial support, or other reasons. The textile industry in China consists of several sub-units such as knitting, weaving, seizing, power looms, and manual drying units. Therefore, we considered all these units for data collection, and the percentages are presented.

Table 1. Sample statistic frequency distribution.

\begin{tabular}{cccc}
\hline Particulars & Description & Frequency & Percentage \\
\hline Gender & Male & 480 & $100 \%$ \\
\hline & $18-25$ & 28 & $5.83 \%$ \\
Age (in years) & $26-32$ & 80 & $16.67 \%$ \\
& $33-39$ & 113 & $23.54 \%$ \\
& $40-46$ & 132 & $27.50 \%$ \\
Educational qualification & 47 Above & 127 & $32.50 \%$ \\
& Middle school & 156 & $27.50 \%$ \\
& High school & $20.41 \%$ \\
& Graduation level & 132 & $17.91 \%$ \\
& University level & $1.67 \%$ \\
\hline Business sector & Professional education & 86 & $38.77 \%$ \\
& Power looms & $15.62 \%$ \\
& Weaving & $11.25 \%$ \\
& Manul drying units & 75 & $17.91 \%$ \\
& Knitting & 54 & $16.45 \%$ \\
\hline & Seizing & 86 & $9.37 \%$ \\
& $1-5$ years & $23.33 \%$ \\
& 6-10 years & 45 & $20.22 \%$ \\
& $11-15$ years & 112 & $17.29 \%$ \\
& $16-20$ years & 97 & $11.67 \%$ \\
\hline
\end{tabular}

\subsection{The Measures}

The researchers developed a structured questionnaire to ensure the content and the realistic and practical implications of the research model. All the studied variables were constructed (adopted and adapted) and operationalized by using the existing literature on sustainable entrepreneurial performance, knowledge-sharing capacity, innovative capacity, dynamic capability, and opportunity recognition. To measure all constructs, a 5-point Likert scale was used ranging from 1 to 5 (from strongly disagree to strongly agree).

As shown in the Appendix A, the questionnaire for all studied constructs. To measure knowledge-sharing behavior, five items were adapted from the study by Hsu [98]. The scale was validated with widely used research and commented on by [99]. To evaluate the innovative capacity, the researchers adopted five measuring scales developed by Hurley [100]. The dynamic capability was measured through six items and the scale 
was adapted from [101] and commented on by [51]. The six measurement items of opportunity recognition were measured from the study by [88]. The 11 items of sustainable entrepreneurship performance were adopted and measured from the study by [102]. To measure the organizational performance with four items, a scale was adopted from the study by [103].

\subsection{Measurement Model}

The Statistical Packages for Social Sciences (SPSS) and Smart-PLS software brings fluency and reduce the flaws from collected data. Structural equation modeling, applied to estimate causal and empirical models in research [104], examines the correlation between latent constructs. Smart Partial Least Square (Smart-PLS) tests the path model or SEM for multivariate analysis [105]. Smart PLS measures formative and reflective models and mediating and moderation relationships among the latent constructs in research. Table 2 shows the reliability and validity of the latent constructs. A test was applied to analyze and extract the factor loading of the studied variables; as per the rule of thumb, the factor loading values should be at least 0.7 . The convergent validity with Cronbach's alpha, rho_A, the average value extracted [106], composite reliability [107], and confirmatory factor analysis (CFA) was above thrush hold value and acceptable [108]. The values for convergent validity should be higher than the thrush hold values; rho_A $\geq 0.7, \mathrm{CR} \geq 0.8$, $\mathrm{AVE} \geq 0.50$, and $\mathrm{CA} \geq 0.80$ [109]. The convergent validity for all variables was acceptable and in the range [110].

Table 2. Measurement model.

\begin{tabular}{|c|c|c|c|c|c|}
\hline Variables and Constructs & Loadings & CA & rho-A & CR & AVE \\
\hline Knowledge-Sharing Behavior & & 0.952 & 0.954 & 0.953 & 0.801 \\
\hline KSB1 & 0.929 & & & & \\
\hline KSB2 & 0.916 & & & & \\
\hline KSB3 & 0.880 & & & & \\
\hline KSB4 & 0.839 & & & & \\
\hline KSB5 & 0.907 & & & & \\
\hline Innovative Capacity & & 0.934 & 0.935 & 0.934 & 0.738 \\
\hline IC1 & 0.892 & & & & \\
\hline IC2 & 0.846 & & & & \\
\hline IC 3 & 0.870 & & & & \\
\hline IC4 & 0.881 & & & & \\
\hline IC5 & 0.804 & & & & \\
\hline Dynamic Capability & & 0.945 & 0.952 & 0.946 & 0.746 \\
\hline DC1 & 0.845 & & & & \\
\hline DC2 & 0.791 & & & & \\
\hline DC3 & 0.916 & & & & \\
\hline DC4 & 0.959 & & & & \\
\hline DC5 & 0.852 & & & & \\
\hline DC6 & 0.895 & & & & \\
\hline Sustainable Entrepreneurship Performance & & 0.949 & 0.950 & 0.949 & 0.629 \\
\hline SEP1 & 0.720 & & & & \\
\hline SEP2 & 0.754 & & & & \\
\hline SEP3 & 0.830 & & & & \\
\hline SEP4 & 0.836 & & & & \\
\hline SEP5 & 0.756 & & & & \\
\hline SEP6 & 0.899 & & & & \\
\hline SEP7 & 0.794 & & & & \\
\hline SEP8 & 0.796 & & & & \\
\hline SEP9 & 0.783 & & & & \\
\hline SEP10 & 0.760 & & & & \\
\hline EP11 & 0.779 & & & & \\
\hline Opportunity Recognition & & 0.940 & 0.941 & 0.940 & 0.722 \\
\hline OR1 & 0.824 & & & & \\
\hline OR2 & 0.884 & & & & \\
\hline OR3 & 0.804 & & & & \\
\hline OR4 & 0.920 & & & & \\
\hline OR5 & 0.848 & & & & \\
\hline OR6 & 0.813 & & & & \\
\hline Organizational Performance & & 0.933 & 0.934 & 0.933 & 0.777 \\
\hline OP1 & 0.909 & & & & \\
\hline OP2 & 0.835 & & & & \\
\hline OP3 & 0.888 & & & & \\
\hline OP4 & 0.892 & & & & \\
\hline
\end{tabular}




\subsection{Common Method Bias and Multicollinearity Test}

The Harman test was applied to the data to determine common method bias (CMB) and the variance inflation factor (VIF) to avoid multicollinearity. There is no issue of common method bias if the merged factors are less than $50 \%$ of the variance [111]. Therefore, the authors performed a principle rotated matrix and showed that the first factor of the initial eigenvalue explained $40.24 \%$ of the total variance.

\subsection{Discriminant Validity}

The primary method of the Fornell-Larcker criterion was used to measure the discriminant validity and cross-loadings [112]. Table 3 shows that the approach of the FornellLarcker criterion was fitted to the current research model in discriminant validity.

Table 3. Fornell-Larcker criterion.

\begin{tabular}{ccccccc}
\hline & DC & IC & KSB & OP & OR & SEP \\
\hline DC & $\mathbf{0 . 8 6 4}$ & & & & & \\
IC & 0.377 & $\mathbf{0 . 8 5 9}$ & & & & \\
KSB & 0.425 & 0.458 & $\mathbf{0 . 8 9 5}$ & & & \\
OP & 0.448 & 0.420 & 0.515 & $\mathbf{0 . 8 8 1}$ & & \\
OR & 0.368 & 0.202 & 0.247 & 0.415 & $\mathbf{0 . 8 5 0}$ & \\
SEP & 0.415 & 0.467 & 0.452 & 0.490 & 0.379 & $\mathbf{0 . 7 9 3}$ \\
\hline
\end{tabular}

Table 4 shows the applied heterotrait-monotrait ratio (HTMT) analysis, which also explored the discriminant validity values [97], and the values were much closer in HTMT path analysis [110]. The HTMT value should be less than 1 between factors. To clearly distinguish between the two factors, the HTMT ratio should be less than 1 [110], and the below table shows that all the values were in accordance with the threshold values. Therefore, it is concluded that there was no discriminant validity issue.

Table 4. Heterotrait-Monotrait (HTMT) ratios.

\begin{tabular}{ccccccc}
\hline & DC & IC & KSB & OP & OR & SEP \\
\hline DC & & & & & & \\
IC & 0.377 & & & & & \\
KSB & 0.424 & 0.456 & & & \\
OP & 0.449 & 0.420 & 0.515 & & \\
OR & 0.370 & 0.203 & 0.246 & 0.413 & & \\
SEP & 0.411 & 0.466 & 0.451 & 0.490 & 0.379 & \\
\hline
\end{tabular}

\subsection{Structural Model for Entrepreneurial and Organizational Performance}

Figure 2 showed the factor loading of latent constructs with acceptable values $\leq 0.70$. The structural model was measured through Smart-PLS by applying bootstrapping at 500 sub-samples. The standardized root mean square residual (SRMR) was applied to the fitness of the model, and the value for a good model should be $<0.08$ [113]. 


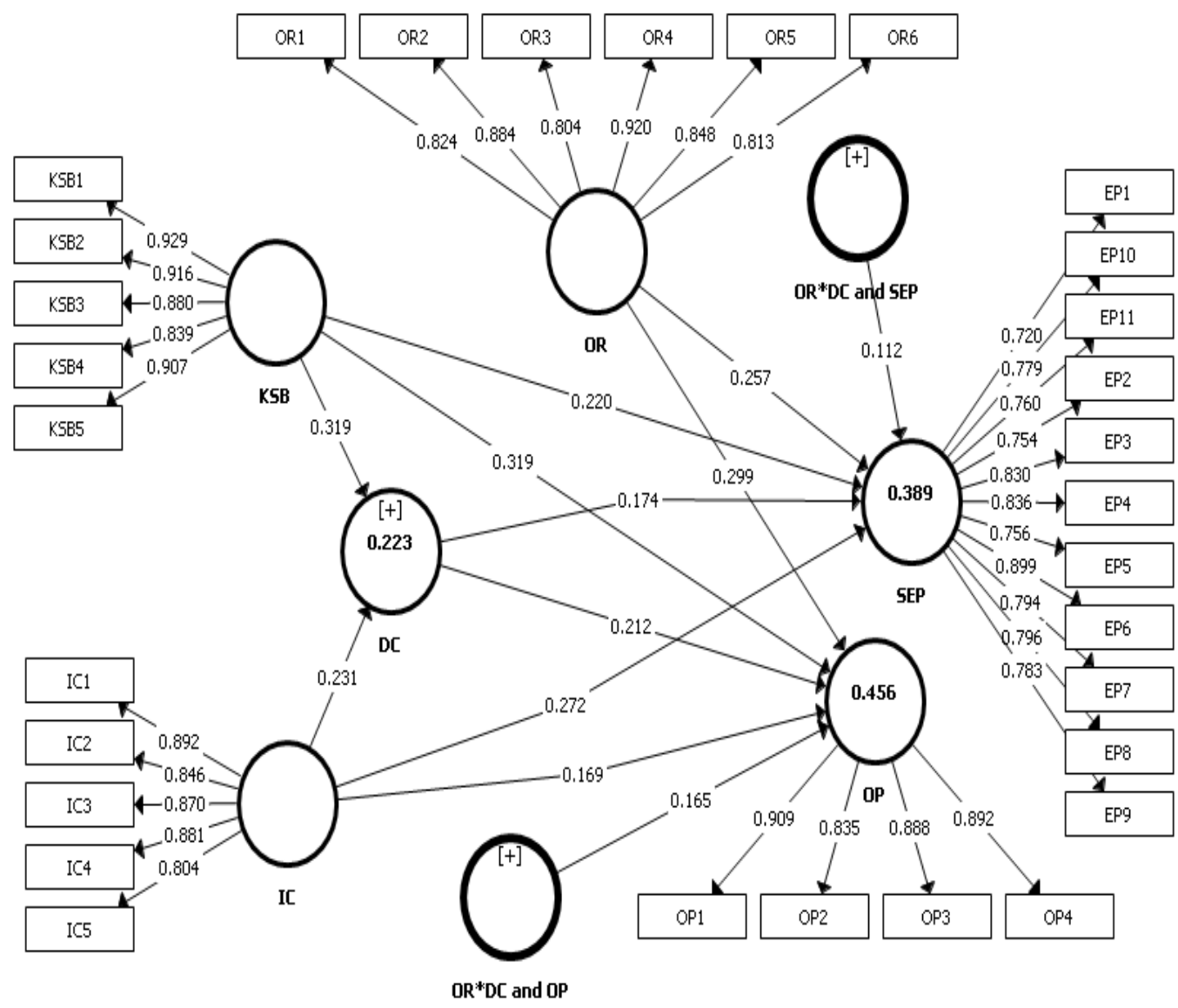

Figure 2. Hypothesis testing of SME performance.

Table 5 shows the direct impacts of all the studied variables. H1a showed a positive and significant impact of KSB on SEP, and therefore $\mathrm{H} 1$ is supported $(\beta=0.276 ; t=6.232$; $p<0.000)$. H1b demonstrated a direct significant and positive effect of KSB on DC, and therefore $\mathrm{H} 2$ is supported $(\beta=0.319 ; \mathrm{t}=7.141 ; p<0.000)$. H2a showed a direct and positive effect of IC on SEP, and is supported $(\beta=0.312 ; \mathrm{t}=6.646 ; p<0.000)$. H2b also showed a significant, direct, and positive effect of IC on DC, and therefore $\mathrm{H} 2 \mathrm{~b}$ is supported $(\beta=0.231 ; t=4.927 ; p<0.000)$. H3a demonstrated a positive and significant effect of $\mathrm{KSB}$ on OP, and therefore is supported $(\beta=0.387 ; t=7.550 ; p<0.000)$. At the same time, H4a showed a direct effect of IC on OP; therefore, $\mathrm{H} 4 \mathrm{a}$ is supported $(\beta=0.218 ; \mathrm{t}=5.133$; $p<0.000)$.

Table 5. Path Coefficients for direct relations.

\begin{tabular}{cccccccc}
\hline Hyp. & Relationships & $\boldsymbol{\beta}$ & Mean & S.D & t-Value & $p$-Value & Decision \\
\hline H1a & KSB $->$ SEP & 0.276 & 0.279 & 0.044 & 6.232 & $\mathbf{0 . 0 0 0}$ & Accepted \\
H1b & KSB - D DC & 0.319 & 0.316 & 0.045 & 7.141 & $\mathbf{0 . 0 0 0}$ & Accepted \\
H2a & IC -> SEP & 0.312 & 0.312 & 0.047 & 6.646 & $\mathbf{0 . 0 0 0}$ & Accepted \\
H2b & IC -> DC & 0.231 & 0.232 & 0.047 & 4.927 & $\mathbf{0 . 0 0 0}$ & Accepted \\
H3a & KSB - > OP & 0.387 & 0.386 & 0.051 & 7.550 & $\mathbf{0 . 0 0 0}$ & Accepted \\
H4a & IC - > OP & 0.218 & 0.217 & 0.042 & 5.133 & $\mathbf{0 . 0 0 0}$ & Accepted \\
H5a & DC - S SP & 0.174 & 0.174 & 0.049 & 3.554 & $\mathbf{0 . 0 0 0}$ & Accepted \\
H5b & DC -> OP & 0.212 & 0.215 & 0.052 & 4.044 & $\mathbf{0 . 0 0 0}$ & Accepted \\
H6a & OR -> SEP & 0.257 & 0.254 & 0.050 & 5.116 & $\mathbf{0 . 0 0 0}$ & Accepted \\
H7a & OR -> OP & 0.299 & 0.296 & 0.051 & 5.907 & $\mathbf{0 . 0 0 0}$ & Accepted \\
\hline
\end{tabular}

H5a showed a significant, direct, and positive effect of DC on SEP, and therefore H5a is supported $(\beta=0.174 ; \mathrm{t}=3.554 ; p<0.000)$. H5b showed a significant effect of DC on OP, 
and therefore $\mathrm{H} 5 \mathrm{~b}$ is supported $(\beta=0.212 ; \mathrm{t}=4.044 ; p<0.000)$. H6a showed a positive effect of OR on SEP, and therefore H6a is supported $(\beta=0.257 ; \mathrm{t}=5.116 ; p<0.000)$. The last direct effect of H7a showed a positive direction of OR on OP; therefore, H7a is supported $(\beta=0.299 ; \mathrm{t}=5.907 ; p<0.000)$.

\subsection{F-Square and Construct Cross-Validated Redundancy}

Table 6 shows the values for the F-square and construct cross-validated redundancy (Q2), wherein a variable in a structural model may be affected by the number of variables. The F-square is a change in the R-square when the model removes an exogenous variable. The F-square is smaller with a value $\geq 0.02$, medium with a value $\geq 0.15$, and large with a value $\geq 0.35$ [114]. The value of the F-square measures the closeness between the two predictors. An average difference of $10 \%$ at all measured time points resulted in an $\mathrm{f} 2$ value of 50 .

Table 6. Value of the F-square.

\begin{tabular}{|c|c|c|c|c|c|c|c|c|}
\hline & DC & IC & KSB & OP & OR & OR*DC and OP & OR*DC and SEP & SEP \\
\hline DC & & & & 0.057 & & & & 0.034 \\
\hline IC & 0.054 & & & 0.039 & & & & 0.090 \\
\hline KSB & 0.104 & & & 0.133 & & & & 0.056 \\
\hline \multicolumn{9}{|l|}{ OP } \\
\hline OR & & & & 0.134 & & & & 0.088 \\
\hline OR*DC and OP & & & & 0.096 & & & & \\
\hline OR*DC and SEP & & & & & & & & 0.040 \\
\hline SEP & & & & & & & & \\
\hline
\end{tabular}

Table 7 also shows the value for the Q-square, which establishes the predictive relevance of the endogenous constructs. Q2 is a predictive relevance measure of whether a model has predictive relevance or not. The value should be great than 0 for $Q 2$, which shows that the model has predictive relevance, and blindfolding was used to extract the value for Q2 in Smart-PLS.

Table 7. Construct cross-validated redundancy.

\begin{tabular}{cc}
\hline Constructs & $\mathbf{Q}^{2}(\mathbf{= 1}-\mathbf{S S E} / \mathbf{S S O})$ \\
\hline DC & 0.149 \\
OP & 0.313 \\
SEP & 0.216 \\
\hline
\end{tabular}

Table 8 shows the indirect effects of KMPs through dynamic capability as a mediator between sustainable entrepreneurship and organizational performance. Furthermore, it also shows the moderating effect of opportunity recognition between dynamic capability with sustainable entrepreneurship and organizational performance. The results for H1c confirm that the DC mediated the relationship between KSB and SEP; therefore, H1c is confirmed $(\beta=0.056 ; t=3.045 ; p<0.002)$. It also shows the partial mediation between KSB and SEP through DC. The results for $\mathrm{H} 2 \mathrm{c}$ show that DC partially mediated the relationship between IC and SEP; therefore, $\mathrm{H} 2 \mathrm{c}$ is supported $(\beta=0.040 ; \mathrm{t}=2.808 ; p<0.005)$. 
Table 8. Path coefficient for indirect relationship.

\begin{tabular}{llllllll}
\hline Hyp. & Relationships & $\boldsymbol{\beta}$ & Mean & SD & t-Value & $p$-Value & Decision \\
\hline H1c & KSB $\rightarrow$ DC $\rightarrow$ SEP & 0.056 & 0.055 & 0.018 & 3.045 & 0.002 & proved \\
H2c & IC $\rightarrow$ DC $\rightarrow$ SEP & 0.040 & 0.041 & 0.014 & 2.808 & 0.005 & proved \\
H3b & KSB $\rightarrow$ DC $\rightarrow$ OP & 0.068 & 0.068 & 0.019 & 3.587 & 0.000 & proved \\
H4b & IC $\rightarrow$ DC $\rightarrow$ OP & 0.049 & 0.050 & 0.017 & 2.840 & 0.005 & proved \\
H6b & OR*DC $\rightarrow$ SEP & 0.112 & 0.113 & 0.026 & 4.373 & 0.000 & Proved \\
H7b & OR DC $\rightarrow$ OP & 0.165 & 0.163 & 0.044 & 3.749 & 0.000 & Proved \\
\hline
\end{tabular}

Furthermore, H3b showed a partial mediating effect of DC between KSB and OP; therefore, H6c is supported $(\beta=0.068 ; \mathrm{t}=3.587 ; p<0.000)$. H4b showed a partial mediating relationship of DC between IC and OP; therefore, H4b is supported $(\beta=0.049 ; \mathrm{t}=4.373$; $p<0.000)$.

Moreover, this study considered the moderating effect of OR on the relationship between DC with the OP and SEP of textile-based SMEs in China. Table 6, which shows $\mathrm{H} 6 \mathrm{~b}$, shows that OR positively and significantly moderated the relationship between DC and SEP $(\beta=0.112 ; t=4.373 ; p<0.000)$. The results for $\mathrm{H} 7 \mathrm{~b}$ also show that $\mathrm{OR}$ strengthened the relationship between DC and OP $(\beta=0.163 ; t=3.749 ; p<0.000)$.

Figures 3 and 4 show the moderating effect of opportunity recognition between dynamic capability with sustainable entrepreneurship and organizational performance [115]. Furthermore, to assess the moderating effects, other rules were applied.

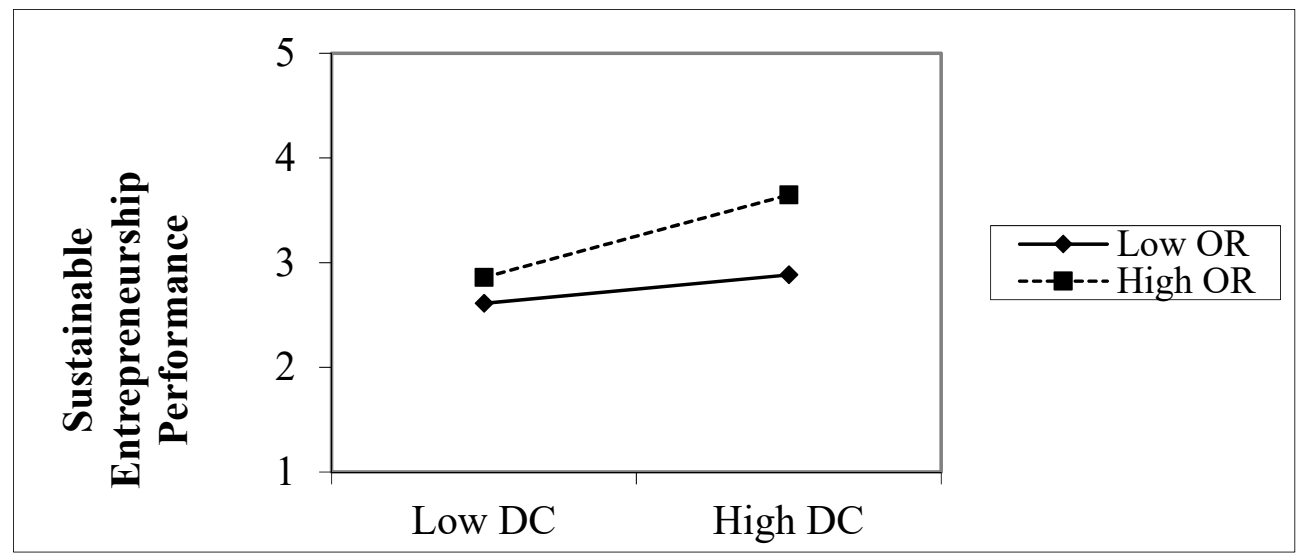

Figure 3. Moderating effect of OR between DC and EP.

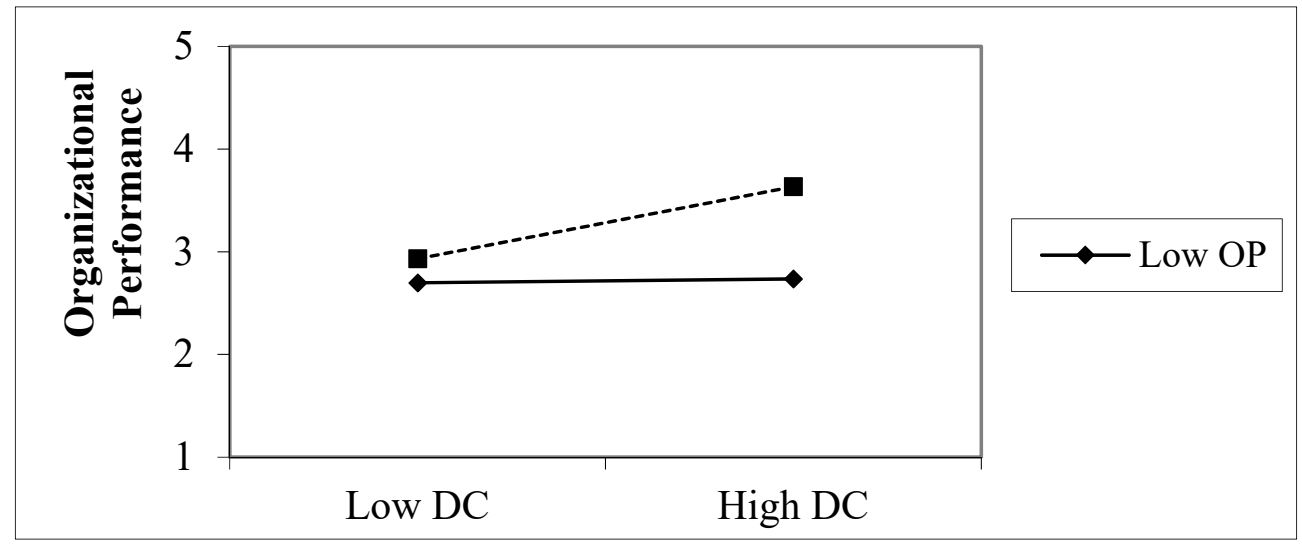

Figure 4. Moderating effect of OR between DC and OP. 
Figure 3 shows that OR was an important factor that positively impacted the relationship between DC and SEP, proving the proposed H6b, which stated that OR has a significant positive moderation effect on the relationship between DC and SEP.

Moreover, Figure 4 shows the moderating effect of OR between dynamic capability and organizational performance, proving $\mathrm{H} 7 \mathrm{~b}$, which stated a positive and significant moderation on the relationship between DC and OP.

To consider the strengthening of a moderator, the R2 of a moderator with a full model was evaluated. The values represent moderate moderator, robust, and moderate moderating effects [116].The moderating effect is not mean causal or irrelevant, but even a small interaction might have a strong and meaningful effects between dynamic capabilities with entrepreneurial and organizational performance. It is suggested that the role of opportunity recognition in the relationship between dynamic capability with entrepreneurial and organizational performance could be significant. Opportunity recognition for SME performance moderated the slope for an association between dynamic capability with sustainable entrepreneurial and organizational performance, reflecting that association becomes stronger when there are more opportunities for entrepreneurs and organizations, as the slope shows in Figures 3 and 4.

Table 9 shows the VIF for the studied variables. As per the rule of thumb, the values should be between 5 to 10, and all values were acceptable [117]. None of the values is above 10 in the table, so there was no multicollinearity issue. To ensure and avoid biasness and multicollinearity for the collected data, several tests were applied: path-coefficient, validity, and reliability [97].

Table 9. Collinearity statistics (VIF).

\begin{tabular}{|c|c|}
\hline $\begin{array}{l}\text { DC1 } \\
\text { DC2 } \\
\text { DC3 } \\
\text { DC4 } \\
\text { DC5 } \\
\text { DC6 }\end{array}$ & $\begin{array}{l}2.910 \\
2.234 \\
3.426 \\
4.841 \\
4.626 \\
4.906\end{array}$ \\
\hline $\begin{array}{c}\text { EP1 } \\
\text { EP10 } \\
\text { EP11 } \\
\text { EP2 } \\
\text { EP3 } \\
\text { EP4 } \\
\text { EP5 } \\
\text { EP6 } \\
\text { EP7 } \\
\text { EP8 } \\
\text { EP9 }\end{array}$ & $\begin{array}{l}2.273 \\
2.824 \\
2.814 \\
2.823 \\
3.303 \\
2.850 \\
2.249 \\
3.491 \\
3.667 \\
3.059 \\
2.300\end{array}$ \\
\hline $\begin{array}{l}\text { IC1 } \\
\text { IC2 } \\
\text { IC3 } \\
\text { IC4 } \\
\text { IC5 }\end{array}$ & $\begin{array}{l}2.278 \\
2.680 \\
4.692 \\
4.261 \\
4.299\end{array}$ \\
\hline $\begin{array}{l}\text { KSB1 } \\
\text { KSB2 } \\
\text { KSB3 } \\
\text { KSB4 } \\
\text { KSB5 }\end{array}$ & $\begin{array}{l}4.253 \\
4.857 \\
4.264 \\
2.893 \\
4.333\end{array}$ \\
\hline $\begin{array}{l}\text { OP1 } \\
\text { OP2 } \\
\text { OP3 } \\
\text { OP4 }\end{array}$ & $\begin{array}{l}3.378 \\
3.139 \\
4.905 \\
4.220\end{array}$ \\
\hline $\begin{array}{l}\text { OR1 } \\
\text { OR2 } \\
\text { OR3 } \\
\text { OR4 } \\
\text { OR5 } \\
\text { OR6 }\end{array}$ & $\begin{array}{l}4.069 \\
4.088 \\
2.654 \\
2.478 \\
4.436 \\
3.239\end{array}$ \\
\hline
\end{tabular}

\section{Discussion}

This research was conducted to explore the influence of knowledge management practices on organizational and sustainable entrepreneurship performance, with mediating 
and moderating effects of dynamic capabilities and opportunity recognition. The path coefficient supported the provided hypotheses empirically and identified significant findings, with a $p$-value $<0.05$ and a t-value $>2$.

The results of H1a offer the possibility that KSB has a positive relationship with sustainable entrepreneurship performance, which was previously commented on by [118,119]. This means that KSB can spread important information, which is a valuable asset for sustainable performance [120]. KSB can increase the tendency to understand the organizational domestic and economic challenges an entrepreneur faces in sustainable performance. Knowledge-sharing behavior demonstrates the effect of dynamic capabilities, which help determine, integrate, and reconfigure internal and external capabilities for better sustainable performance. The results support our hypothesis $\mathrm{H} 1 \mathrm{~b}$, which proposed that KSB positively influences DC, which is supported by the explanations and consistent with [51]. The dynamic capability helps enhance the internal resources, competencies, and abilities for performance [121]. The result for H1c offers the possibility of dynamic capability as a mediating effect between knowledge-sharing behavior and sustainable entrepreneurship performance, which is consistent with the study by [98]. The explanation for the mediating role of dynamic capability energizes the entrepreneurial performance with knowledge-sharing behavior [122].

The results of $\mathrm{H} 2 \mathrm{a}$ offer the possibility of innovative capacity on entrepreneurship performance that was commented on by [100] and other studies by [119] and was associated with the findings of the study. The result for $\mathrm{H} 2 \mathrm{~b}$ suggests that innovative capacity influenced dynamic capability positively, which is consistent with the prior studies of [123]. The result for $\mathrm{H} 2 \mathrm{c}$ confirms that innovative capacity triggered dynamic capability for entrepreneurial performance, and the results are consistent with the studies of $[42,100]$. These results contribute to innovative capacity with dynamic capability for entrepreneurial performance. When entrepreneurs face adversity, innovative capacity contributes to acquiring, creating, and applying inner values. Innovative capacity boosts decision-making power and leadership abilities; assists as a financial adviser in the organization; is attentive to the organization, awareness, and allocation of better opportunities with better substitutes; and benefits sustainable entrepreneurial performance [124]. Furthermore, the results of H6 confirm that dynamic capacity positively mediated the association between innovative capacity and sustainable entrepreneurial performance. These results are consistent with those of previous studies by [70].

The results for H3a suggest that knowledge-sharing behavior significantly impacted organizational performance and was commented on in the studies of [125]. Furthermore, the results of $\mathrm{H} 3 \mathrm{~b}$ suggest that dynamic capabilities positively mediated between knowledgesharing behavior and organizational performance. The study findings prove the proposed hypotheses and are consistent with prior studies [98]. The results of H4a suggest that innovative capacity positively influenced organizational performance, and the study's finding demonstrates the proposed hypothesis, along with the studies of [126]. The results for $\mathrm{H} 4 \mathrm{~b}$ suggest a positive role of dynamic capability as a mediator between innovative capacity and organizational performance, which is also consisted with prior studies [127].

The findings for H5a are meaningful and generally consistent with dynamic capability, and positively affected sustainable entrepreneurship performance and are consistent with $[127,128]$. The results for H5b suggest that dynamic capability positively and significantly affected organizational performance and was commented on by [91] and [129]. The findings for H6a reveal that opportunity recognition positively influenced entrepreneurial performance [87]. Moreover, OR was an important factor that positively impacted the relationship between DC and SEP, proving H6b, which stated that OR has a significant positive moderation effect on the relationship between DC and SEP and is consistent with [90]. The results for H7a suggest that opportunity recognition had a positive and significant impact on organizational performance, which was commented on in prior studies [130]. In contrast, the results for H7b suggest that opportunity recognition moderated between dynamic capability and organizational performance and was commented on in [131,132]. 
The study findings conclude that KMPs regulated the SME sustainable entrepreneurship and organizational performance.

Furthermore, the results from numerous pieces of literature and legislators indicate that DCs have an important role in SME performance and the OR moderating between DCs with SEP and OP. Prior studies suggested that opportunity recognition intends to enhance SME performance. Thus, the government is focused on establishing SMEs with different kinds of support programs and management just like developed countries, which will lead to long-term benefits, growth, and sustainability of the economy.

\section{Conclusions}

This research, an empirical study of 480 entrepreneurs and organizational owners, explored the impact of KMPs (knowledge-sharing behavior and innovative capacity) on SMEs' sustainable entrepreneurship and organizational performance. Furthermore, the study also explored the mediation and moderation (dynamic capability and opportunity recognition) between sustainable entrepreneurship and organizational performance. To be specific, this study considered KMPs as an important antecedent for SME performance. Thus, the study results indicate that the validity and reliability of the measured scales for knowledge-sharing behavior was 0.952 , for innovative capacity was 0.934 , for dynamic capability was 0.945 , for opportunity recognition was 0.940 , for entrepreneurial performance was 0.949 , and for organizational performance was 0.933 . To test and assess the multiple levels of latent and observed variables, this method was suitable for evaluating the theory $[107,133]$. The studied path coefficient provided empirical support to the proposed seven hypotheses $(\mathrm{a}, \mathrm{b}, \mathrm{c})$, and found significant findings with a $p$-value $<0.05$ and t-value $>2$ [106].

This study's findings indicate that knowledge management methods had a considerable impact on SME entrepreneurial performance, as evidenced by the significant beta coefficient, t-values, and $p$-values. The study objective was to examine the concept of knowledge management practices to provide better services (knowledge-sharing behavior, innovative capacity) to the SMEs' entrepreneurial and organizational performance. Secondly, the study examined the mediating and moderating role of dynamic capability and opportunity recognition for SMEs' entrepreneurial and organizational performance. Thus, the findings of this study also identified that the promotion of SMEs' entrepreneurial and organizational performance would play a vital role in developing the weak economy. Dynamic capabilities and opportunity recognition with capital support from the government would also be important and support elements for SME performance.

SME entrepreneurs and organizations face many challenges for better performance, lack proper guidance, have inadequate facilities and infrastructure, and need educational and technical skills. It was surprising to learn that most SMEs do not survive more than a few years. In this situation, knowledge management practices play an important role in developing and growing small-medium businesses. Numerous studies have explored the critical role of knowledge management practices in SME performance and economic growth. The Republic of China has taken the initiative to support SMEs through different departments, the Small and Medium Enterprises Development Authority (SMEDA), and incubation centers, which are doing a great job for entrepreneurs and SME organizations. Still, they needed to work on SME enhancement and performance. The guidance in recognizing opportunities for private SMEs must be fast and advanced, which will benefit SME performance.

The findings of this study also suggest that the government should conduct a onewindow strategy to guide SMEs for better performance, which may be linked with other concerned departments, such as those assisting in a startups or new businesses or those that run existing businesses. This study focused on textile-based SMEs and wanted to improve their productivity. The government needs to establish different technical service centers for training and planning for under-trained staff for guidance. Furthermore, these research findings also suggest that if the government wants the SMEs to grow and play a 
crucial role in the growing economy, then the emerging and emerging economies should develop SMEs with proper and appropriate institutions.

\section{Theoretical Implications}

The study contributes to the existing literature on SME performance (entrepreneurial and organizational). The study contributes to the literature on SMEs with KMPs, capabilities, and opportunities. This research will help develop government and non-government SMEs (textile-based), which will increase the graph of business successors and contribute to SME performance. The study used a combination of different theories that were not used before and also suggests that textile-based SMEs are linked to entrepreneurship theory and organizational learning theory, which plays a vital role between knowledge management practices, dynamic capabilities, and opportunity recognition for SME performance. This study will also help future researchers in similar fields, leading to better results.

\section{Practical Implications}

This study will also help SMEs build up a more powerful method for moving information in an organization to foster a better atmosphere for accomplishing objectives against competitors. It is important for organizations' performance and economy because they are facing a deficiency of inner and outer data, influencing performance. For instance, an innovation with the dynamic capabilities of SMEs develops organizational and entrepreneurial quality across the organizational boundaries. This study can also be helpful to fresh researchers in terms of research and existing entrepreneurs in terms of better performance. This study also brings the literature on knowledge management practices into a broader perspective for SME performance. Therefore, this study also contributes to the conceptual framework for entrepreneurial and organizational performance.

\section{Limitations and Future Research Directions}

The study has a few limitations, which need to be acknowledged. The data were collected from one source or the same source. The discriminant validity in the CFA analysis confirmed the directional relations of all constructs. Therefore, caution should be applied during interpretation. There are a few limitations and future directions in this study, such as the study being limited to a cross-sectional analysis, not longitudinal analysis. It is recommended for researchers to conduct longitudinal analysis for better results and include more SME disciplines from China. Future studies may include control variables (government regulation and demographics).

This study sample was limited, and the respondents were $100 \%$ males due to the nature of the business. This finding might have been impacted by sex separation. Thus, for future examination, replication of the current review ought to consider sex. Last, the proposed research model was tried on Chinese male businesspeople and associations going through male finance managers. Notwithstanding, for future proposals, examinations might consider more and various businesses, including large amounts of test information with male and female businesspeople. This exploration might repeat and build on the examination model for increased relevance of the findings.

Author Contributions: Conceptualization, S.F.A. and A.A.Q.; methodology, S.F.A. and J.Z.; software, N.S.; validation, M.N., N.S. and K.O.; formal analysis, M.N.; investigation, A.A.Q. and J.Z.; resources, J.Z.; data curation, A.A.Q. and J.Z.; writing-original draft preparation, S.F.A.; writing-review and editing, S.F.A. and N.S.; visualization, M.N.; supervision, J.Z.; project administration, J.Z. and A.A.Q.; funding acquisition, J.Z. All authors have read and agreed to the published version of the manuscript.

Funding: This research received no external funding.

Institutional Review Board Statement: There is no conflict of interest of animal or patients in this study.

Informed Consent Statement: There is no conflict of interest of animal or patients in this study. 
Data Availability Statement: Data will be provided on request.

Conflicts of Interest: There is no conflict of interest while conducting research.

\section{Appendix A}

Please select a number from the scale below that best describes your response.

Table A1. 1-Strongly disagree, 2—Disagree, 3-Neutral, 4-Agree, 5-Strongly agree.

\begin{tabular}{|c|c|c|c|c|c|c|}
\hline \multirow[t]{2}{*}{ Sr \# } & \multirow{2}{*}{$\begin{array}{l}\text { Questions } \\
\text { Entrepreneurial Performance }\end{array}$} & \multicolumn{5}{|c|}{ Responses } \\
\hline & & 1 & 2 & 3 & 4 & 5 \\
\hline 1 & $\begin{array}{l}\text { Understands work responsibilities, scope of job tasks, and routines to be } \\
\text { performed. }\end{array}$ & & & & & \\
\hline 2 & Completes work thoroughly, accurately, and according & & & & & \\
\hline 2 & to specifications. & & & & & \\
\hline 3 & $\begin{array}{c}\text { Avoids law or rules infractions, excessive absenteeism, or other behaviors that } \\
\text { may have a negative impact on the organization }\end{array}$ & & & & & \\
\hline 4 & $\begin{array}{l}\text { or employees. } \\
\text { Clearly and appropriately communicates information in writing. }\end{array}$ & & & & & \\
\hline 5 & Clearly and appropriately communicates information orally. & & & & & \\
\hline & Contributes to the top management team by supporting other team members, & & & & & \\
\hline 6 & $\begin{array}{c}\text { resolving conflict between members, and contributing to general team } \\
\text { functioning. }\end{array}$ & & & & & \\
\hline 7 & $\begin{array}{c}\text { Supports peers and performs cooperative, considerate, and helpful acts that } \\
\text { assist coworkers' performance. }\end{array}$ & & & & & \\
\hline 8 & $\begin{array}{c}\text { Forms goals, allocates resources to meet them, and monitors progress toward } \\
\text { them. }\end{array}$ & & & & & \\
\hline 9 & $\begin{array}{c}\text { Influences the performance of others in achieving the goals of the organization. } \\
\text { Includes communicating goals to others, modeling appropriate behaviors, } \\
\text { coaching others to help them attain goals, and providing reinforcement upon } \\
\text { the attainment of goals. }\end{array}$ & & & & & \\
\hline 10 & $\begin{array}{l}\text { Overcomes natural resistance to organizational change; strives to behave in } \\
\text { ways that are consistent with the change goals and corporate strategy. }\end{array}$ & & & & & \\
\hline & Effectively manages the transition period while organizational changes are & & & & & \\
\hline 11 & $\begin{array}{l}\text { being implemented. This involves dealing with the rate at which change is } \\
\text { introduced and the processes used to introduce change. }\end{array}$ & & & & & \\
\hline & Organizational Performance & 1 & 2 & 3 & 4 & 5 \\
\hline 1 & The firm's performance measured by return on assets & & & & & \\
\hline 2 & The firm's performance measured by return on equity & & & & & \\
\hline 3 & The firm's performance measured by return on sales & & & & & \\
\hline 4 & The firm's market share in its main products and markets & & & & & \\
\hline & Knowledge-Sharing Behavior & 1 & 2 & 3 & 4 & 5 \\
\hline 1 & I frequently participate in knowledge-sharing activities in the organization. & & & & & \\
\hline 2 & $\begin{array}{l}\text { I usually spend a lot of time on knowledge-sharing activities in the } \\
\text { organization. }\end{array}$ & & & & & \\
\hline 3 & $\begin{array}{c}\text { When participating in the organization meetings I usually actively share my } \\
\text { knowledge with others. }\end{array}$ & & & & & \\
\hline 4 & $\begin{array}{c}\text { When discussing complicated issues I am usually involved in the subsequent } \\
\text { interaction. }\end{array}$ & & & & & \\
\hline 5 & $\begin{array}{c}\text { I usually involve myself in discussions of various topics rather than specific } \\
\text { topics. }\end{array}$ & & & & & \\
\hline & Innovative Capacity & 1 & 2 & 3 & 4 & 5 \\
\hline 1 & Risk taking is encouraged in our firm. & & & & & \\
\hline 2 & Creativity is encouraged in our firm. & & & & & \\
\hline 3 & Management actively seeks innovative ideas. & & & & & \\
\hline 4 & Management is tolerant of mistakes when taking risks. & & & & & \\
\hline 5 & The firm is often first to market with new products and services. & & & & & \\
\hline 1 & $\begin{array}{l}\text { Dynamic Capability } \\
\text { Absorb new knowledge from market source }\end{array}$ & 1 & 2 & 3 & 4 & 5 \\
\hline 2 & Encourage knowledge contributions and sharing in the restaurant & & & & & \\
\hline 3 & Stored knowledge is accessed and applied & & & & & \\
\hline 4 & Use knowledge to improve efficiency & & & & & \\
\hline 5 & Makes knowledge accessible to those who need it & & & & & \\
\hline 6 & Quickly apply knowledge to critical competitive needs & & & & & \\
\hline & Opportunity Recognition & 1 & 2 & 3 & 4 & 5 \\
\hline 1 & $\begin{array}{c}\text { You carry out market research to identify new product/service ideas or new } \\
\text { markets. }\end{array}$ & & & & & \\
\hline 2 & You look for and maintain a good relationship with business colleagues to & & & & & \\
\hline 3 & Meetings with customers are important. & & & & & \\
\hline 4 & You know that rapid changes in technology can affect your business. & & & & & \\
\hline 5 & Your organizational structure is flexible to adapt to changes. & & & & & \\
\hline 6 & $\begin{array}{l}\text { You have enough experience to cope with the unexpected changes in the } \\
\text { industry. }\end{array}$ & & & & & \\
\hline
\end{tabular}

\section{References}

1. Li, C.; Ashraf, S.F.; Shahzad, F.; Bashir, I.; Murad, M.; Syed, N.; Riaz, M. Influence of Knowledge Management Practices on Entrepreneurial and Organizational Performance: A Mediated-Moderation Model. Front. Psychol. 2020, 11, 2862.

2. Yasir, N.; Mahmood, N.; Mehmood, H.S.; Babar, M.; Irfan, M.; Liren, A. Impact of environmental, social values and the consideration of future consequences for the development of a sustainable entrepreneurial intention. Sustainability 2021, 13, 2648. [CrossRef] 
3. Zaim, H.; Muhammed, S.; Tarim, M. Relationship between knowledge management processes and performance: Critical role of knowledge utilization in organizations. Knowl. Manag. Res. Pract. 2019, 17, 24-38. [CrossRef]

4. Makhloufi, L.; Laghouag, A.A.; Ali Sahli, A.; Belaid, F. Impact of Entrepreneurial Orientation on Innovation Capability: The Mediating Role of Absorptive Capability and Organizational Learning Capabilities. Sustainability 2021, 13, 5399. [CrossRef]

5. Wahda, W. Mediating effect of knowledge management on organizational learning culture toward organization performance. J. Manag. Dev. 2017, 36, 846-858. [CrossRef]

6. Youssef, A.B.; Boubaker, S.; Omri, A. Entrepreneurship and sustainability: The need for innovative and institutional solutions Technol. Forecast. Soc. Change 2018, 129, 232-241. [CrossRef]

7. Acs, Z.J.; Estrin, S.; Mickiewicz, T.; Szerb, L. Entrepreneurship, institutional economics, and economic growth: An ecosystem perspective. Small Bus. Econ. 2018, 51, 501-514. [CrossRef]

8. González-Serrano, M.H.; Añó Sanz, V.; González-García, R.J. Sustainable sport entrepreneurship and innovation: A bibliometric analysis of this emerging field of research. Sustainability 2020, 12, 5209. [CrossRef]

9. Kordab, M.; Raudeliūnienè, J.; Meidutè-Kavaliauskienè, I. Mediating Role of Knowledge Management in the Relationship between Organizational Learning and Sustainable Organizational Performance. Sustainability 2020, 12, 10061. [CrossRef]

10. Ngah, R.; Tai, T.; Bontis, N. Knowledge management capabilities and organizational performance in roads and transport authority of Dubai: The mediating role of learning organization. Knowl. Process Manag. 2016, 23, 184-193. [CrossRef]

11. Cerchione, R.; Esposito, E. A systematic review of supply chain knowledge management research: State of the art and research opportunities. Int. J. Prod. Econ. 2016, 182, 276-292.

12. Scuotto, V.; Magni, D.; Palladino, R.; Nicotra, M. Triggering disruptive technology absorptive capacity by CIOs. Explorative research on a micro-foundation lens. Technol. Forecast. Soc. Change 2022, 174, 121234. [CrossRef]

13. Chopra, M.; Saini, N.; Kumar, S.; Varma, A.; Mangla, S.K.; Lim, W.M. Past, present, and future of knowledge management for business sustainability. J. Clean. Prod. 2021, 328, 129592.

14. Alaarj, S.; Abidin-Mohamed, Z.; Bustamam, U.S.B.A. Mediating role of trust on the effects of knowledge management capabilities on organizational performance. Procedia-Soc. Behav. Sci. 2016, 235, 729-738. [CrossRef]

15. Ashraf, S.F.; Li, C.; Butt, R.; Naz, S.; Zafar, Z. Education as Moderator: Integrative Effect towards Succession Planning Process of Small Family Businesses. Pac. Bus. Rev. Int. 2019, 11, 107-123.

16. Urban, B.; Kongo, M. The relevance of human capital to firm performance: A focus on the retail industry in Kinshasa, Democratic Republic of Congo. Acta Commer. 2015, 15, 1-9. [CrossRef]

17. Azaizah, N.; Reychav, I.; Raban, D.R.; Simon, T.; McHaney, R. Impact of ESN implementation on communication and knowledgesharing in a multi-national organization. Int. J. Inf. Manag. 2018, 43, 284-294. [CrossRef]

18. Santoro, G.; Thrassou, A.; Bresciani, S.; Del Giudice, M. Do knowledge management and dynamic capabilities affect ambidextrous entrepreneurial intensity and firms' performance? IEEE Trans. Eng. Manag. 2019, 68, 378-386. [CrossRef]

19. Awan, U.; Khattak, A.; Rabbani, S.; Dhir, A. Buyer-driven knowledge transfer activities to enhance organizational sustainability of suppliers. Sustainability 2020, 12, 2993. [CrossRef]

20. Hasan, F.S.; Almubarak, M.M.S. Factors influencing women entrepreneurs' performance in SMEs. World J. Entrep. Manag. Sustain. Dev. 2016, 12. [CrossRef]

21. Abuaddous, H.Y.; Al Sokkar, A.A.; Abualodous, B.I. The impact of knowledge management on organizational performance. Int. J. Adv. Comput. Sci. Appl. 2018, 9, 204-208. [CrossRef]

22. Mangenda Tshiaba, S.; Wang, N.; Ashraf, S.F.; Nazir, M.; Syed, N. Measuring the Sustainable Entrepreneurial Performance of Textile-Based Small-Medium Enterprises: A Mediation-Moderation Model. Sustainability 2021, 13, 11050. [CrossRef]

23. Magni, D.; Scuotto, V.; Pezzi, A.; Del Giudice, M. Employees' acceptance of wearable devices: Towards a predictive model. Technol. Forecast. Soc. Change 2021, 172, 121022. [CrossRef]

24. Lam, L.; Nguyen, P.; Le, N.; Tran, K. The relation among organizational culture, knowledge management, and innovation capability: Its implication for open innovation. J. Open Innov. Technol. Mark. Complex. 2021, 7, 66. [CrossRef]

25. van Reijsen, J.; Helms, R.; Batenburg, R.; Foorthuis, R. The impact of knowledge management and social capital on dynamic capability in organizations. Knowl. Manag. Res. Pract. 2015, 13, 401-417. [CrossRef]

26. Mohamed, M.; Stankosky, M.; Mohamed, M. An empirical assessment of knowledge management criticality for sustainable development. J. Knowl. Manag. 2009, 13, 271-286. [CrossRef]

27. Salder, J.; Gilman, M.; Raby, S.; Gkikas, A. Beyond linearity and resource-based perspectives of SME growth. J. Small Bus. Strategy 2020, 30, 1-17.

28. Schaltegger, S.; Wagner, M. Sustainable entrepreneurship and sustainability innovation: Categories and interactions. Bus. Strategy Environ. 2011, 20, 222-237. [CrossRef]

29. Martins, V.W.B.; Rampasso, I.S.; Anholon, R.; Quelhas, O.L.G.; Leal Filho, W. Knowledge management in the context of sustainability: Literature review and opportunities for future research. J. Clean. Prod. 2019, 229, 489-500. [CrossRef]

30. Liu, H.; Li, G. Linking transformational leadership and knowledge sharing: The mediating roles of perceived team goal commitment and perceived team identification. Front. Psychol. 2018, 9, 1331. [CrossRef] [PubMed]

31. Vargas, N.; Lloria, M.B.; Salazar, A.; Vergara, L. Effect of exploitation and exploration on the innovative as outcomes in entrepreneurial firms. Int. Entrep. Manag. J. 2018, 14, 1053-1069. 
32. Lotfi, M.; Yousefi, A.; Jafari, S. The effect of emerging green market on green entrepreneurship and sustainable development in knowledge-based companies. Sustainability 2018, 10, 2308. [CrossRef]

33. Eikelenboom, M.; de Jong, G. The impact of dynamic capabilities on the sustainability performance of SMEs. J. Clean. Prod. 2019, 235, 1360-1370.

34. Lüdeke-Freund, F. Sustainable entrepreneurship, innovation, and business models: Integrative framework and propositions for future research. Bus. Strategy Environ. 2020, 29, 665-681. [CrossRef]

35. LIU, S.-M.; HU, R.; KANG, T.-W. The effects of absorptive capability and innovative culture on innovation performance: Evidence from Chinese high-tech firms. J. Asian Financ. Econ. Bus. 2021, 8, 1153-1162.

36. Lane, P.; Salk, J.; Lyles, M. Knowledge acquisition and performance in transitional economy international joint ventures. Strateg. Manag. J. 2001, 22, 97-102.

37. Kurniawan, P.; Hartati, W.; Qodriah, S.; Badawi, B. From knowledge sharing to quality performance: The role of absorptive capacity, ambidexterity and innovation capability in creative industry. Manag. Sci. Lett. 2020, 10, 433-442. [CrossRef]

38. Lin, Y.; Wu, L.-Y. Exploring the role of dynamic capabilities in firm performance under the resource-based view framework. J. Bus. Res. 2014, 67, 407-413.

39. Hung, R.Y.Y.; Yang, B.; Lien, B.Y.-H.; McLean, G.N.; Kuo, Y.-M. Dynamic capability: Impact of process alignment and organizational learning culture on performance. J. World Bus. 2010, 45, 285-294. [CrossRef]

40. Ardichvili, A.; Cardozo, R.; Ray, S. A theory of entrepreneurial opportunity identification and development. J. Bus. Ventur. 2003, 18, 105-123. [CrossRef]

41. Jiang, W.; Chai, H.; Shao, J.; Feng, T. Green entrepreneurial orientation for enhancing firm performance: A dynamic capability perspective. J. Clean. Prod. 2018, 198, 1311-1323.

42. Protogerou, A.; Caloghirou, Y.; Lioukas, S. Dynamic capabilities and their indirect impact on firm performance. Ind. Corp. Change 2012, 21, 615-647. [CrossRef]

43. Chung, L.H.; Gibbons, P.T.J.G.; Management, O. Corporate entrepreneurship: The roles of ideology and social capital. Group Organ. Manag. 1997, 22, 10-30. [CrossRef]

44. Yi, G. From green entrepreneurial intentions to green entrepreneurial behaviors: The role of university entrepreneurial support and external institutional support. Int. Entrep. Manag. J. 2021, 17, 963-979. [CrossRef]

45. Kloepfer, K.; Castrogiovanni, G.J. Entrepreneurship: Venture creation subprocesses, subdomains, and interfaces. Int. Entrep. Manag. J. 2018, 14, 681-696. [CrossRef]

46. Gast, J.; Gundolf, K.; Cesinger, B. Doing business in a green way: A systematic review of the ecological sustainability entrepreneurship literature and future research directions. J. Clean. Prod. 2017, 147, 44-56.

47. Domańska, A.; Żukowska, B.; Zajkowski, R.J.P.E. Green entrepreneurship as a connector among social, environmental and economic pillars of sustainable development. Why some countries are more agile? Probl. Ekorozw. 2018, 13, 67-76.

48. Fayolle, A.; Liñán, F.; Moriano, J.A.J.I.E.; Journal, M. Beyond entrepreneurial intentions: Values and motivations in entrepreneurship. Int. Entrep. Manag. J. 2014, 10, 679-689. [CrossRef]

49. Muñoz, P.; Kibler, E.; Mandakovic, V.; Amorós, J.E.J.R.P. Local entrepreneurial ecosystems as configural narratives: A new way of seeing and evaluating antecedents and outcomes. Res. Policy 2020, 104065, in press.

50. Hartono, H.; Halim, E. The impact of knowledge management and entrepreneur's knowledge on innovation and firm performance. Winners 2014, 15, 108-114. [CrossRef]

51. Ferreira, J.; Coelho, A. Dynamic capabilities, innovation and branding capabilities and their impact on competitive advantage and SME's performance in Portugal: The moderating effects of entrepreneurial orientation. Int. J. Innov. Sci. 2020, 12, 255-286.

52. Ambrosini, V.; Bowman, C. What are dynamic capabilities and are they a useful construct in strategic management? Int. J. Manag. Rev. 2009, 11, 29-49. [CrossRef]

53. Grant, R.M. The resource-based theory of competitive advantage: Implications for strategy formulation. Calif. Manag. Rev. 1991, 33, 114-135. [CrossRef]

54. Smirat, I.M.H.; Mohd Shariff, M.N. Strategy, structure, and family firm performance: The relationships of the resource-base view and the contingency approach. Aust. J. Bus. Manag. Res. 2014, 4, 1. [CrossRef]

55. Alvarez, S.A.; Busenitz, L.W. The entrepreneurship of resource-based theory. J. Manag. 2001, 27, 755-775. [CrossRef]

56. Schmitt, A.; Rosing, K.; Zhang, S.X.; Leatherbee, M. A dynamic model of entrepreneurial uncertainty and business opportunity identification: Exploration as a mediator and entrepreneurial self-efficacy as a moderator. Entrep. Theory Pract. 2018, 42, 835-859. [CrossRef]

57. Dada, O.; Fogg, H. Organizational learning, entrepreneurial orientation, and the role of university engagement in SMEs. Int. Small Bus. J. 2016, 34, 86-104. [CrossRef]

58. Hervás-Oliver, J.-L.; Parrilli, M.D.; Rodríguez-Pose, A.; Sempere-Ripoll, F. The drivers of SME innovation in the regions of the EU. Res. Policy 2021, 50, 104316. [CrossRef]

59. Casado-Belmonte, M.d.P.; Marín-Carrillo, G.M.; Terán-Yépez, E.; Capobianco-Uriarte, M.d.1.M. What Is Going on with the Research into the Internationalization of Small and Medium-Sized Enterprises (SMEs)? An Intellectual Structure Analysis into the State-of-the-Art (1990-2018). Publications 2020, 8, 11.

60. Bai, P.; Wu, Q.; Li, Q.; Xue, C.; Zhang, L. Mediating effect of organizational learning capacity on the relationship between relational embeddedness and innovation performance in freight logistics service. Complexity 2021, 2021, 5516599. [CrossRef] 
61. Ngassa, T.C. The influence of entrepreneurship training on profit gaps amongst young male and female entrepreneurs in congo. Mod. Econ. 2021, 12, 1092-1104. [CrossRef]

62. Singh, S.K.; Del Giudice, M. Big data analytics, dynamic capabilities and firm performance. Manag. Decis. 2019, 57, 1729-1733. [CrossRef]

63. Hermawan, I.; Suharnomo, S.; Perdhana, M.S. Inimitable-based innovative entrepreneurship as mediation concepts of information technology roles on organizational performance. Bus. Theory Pract. 2021, 22, 380-391. [CrossRef]

64. Rahmani, B.; Morid, S.P.; Shahed, S.H. Tourism Capacity in the Development of Sustainable Entrepreneurship in Rural Areas (Case Study: Central District of Hamadan). Urban Manag. 2018, 17, 65-97.

65. Ashraf, S.F.; Li, C.; Mehmood, B. A Study of Premium Price Brands with Special Reference to Willingness of Customer to Pay. Int. J. Acad. Res. Bus. Soc. Sci. 2017, 7, 619-639. [CrossRef]

66. Setini, M.; Yasa, N.N.K.; Gede Supartha, I.W.; Ketut Giantari, I.; Rajiani, I. The passway of women entrepreneurship: Starting from social capital with open innovation, through to knowledge sharing and innovative performance. J. Open Innov. Technol. Mark. Complex. 2020, 6, 25. [CrossRef]

67. Revuelto-Taboada, L.; Simón-Moya, V. A comprehensive understanding of social and sustainable entrepreneurship. Manag. Decis. 2012, 50, 744-748.

68. Giniuniene, J.; Jurksiene, L. Dynamic capabilities, innovation and organizational learning: Interrelations and impact on firm performance. Procedia-Soc. Behav. Sci. 2015, 213, 985-991. [CrossRef]

69. Júnior, C.H.; Spe, E.E.; Oliviera, T.; Yanaze, M. Brazilian farmer perception of dynamic capability and performance over the adoption of enterprise resource planning technology. Int. Food Agribus. Manag. Rev. 2020, 23, 515-527. [CrossRef]

70. Cohen, B.; Winn, M.I. Market imperfections, opportunity and sustainable entrepreneurship. J. Bus. Ventur. 2007, 22, 29-49. [CrossRef]

71. Božič, K.; Dimovski, V. Business intelligence and analytics use, innovation ambidexterity, and firm performance: A dynamic capabilities perspective. J. Strateg. Inf. Syst. 2019, 28, 101578.

72. Singh, S.K.; Del Giudice, M.; Chiappetta Jabbour, C.J.; Latan, H.; Sohal, A.S. Stakeholder pressure, green innovation, and performance in small and medium-sized enterprises: The role of green dynamic capabilities. Bus. Strategy Environ. 2022, 31, 500-514. [CrossRef]

73. Khan, F.; Xuehe, Z.; Atlas, F.; Khan, K.; Pitafi, A.; Saleem, M. Impact of absorptive capacity and dominant logic on innovation performance of public sector organizations in Hefei (Anhui Province), China. Manag. Sci. Lett. 2017, 7, 275-284. [CrossRef]

74. Fabrizio, C.M.; Kaczam, F.; de Moura, G.L.; da Silva, L.S.C.V.; da Silva, W.V.; da Veiga, C.P. Competitive advantage and dynamic capability in small and medium-sized enterprises: A systematic literature review and future research directions. Rev. Manag. Sci. 2021, 1-32. [CrossRef]

75. Liu, C.-H.; Horng, J.-S.; Chou, S.-F.; Huang, Y.-C.; Chang, A.Y. How to create competitive advantage: The moderate role of organizational learning as a link between shared value, dynamic capability, differential strategy, and social capital. Asia Pac. $J$. Tour. Res. 2018, 23, 747-764. [CrossRef]

76. Kumar, S.; Sureka, R.; Lim, W.M.; Kumar Mangla, S.; Goyal, N. What do we know about business strategy and environmental research? Insights from Business Strategy and the Environment. Bus. Strategy Environ. 2021, 30, 3454-3469. [CrossRef]

77. Teece, D.; Peteraf, M.; Leih, S. Dynamic capabilities and organizational agility: Risk, uncertainty, and strategy in the innovation economy. Calif. Manag. Rev. 2016, 58, 13-35. [CrossRef]

78. Khaksar, S.M.S.; Chu, M.-T.; Rozario, S.; Slade, B. Knowledge-based dynamic capabilities and knowledge worker productivity in professional service firms The moderating role of organisational culture. Knowl. Manag. Res. Pract. 2020, 1-18. [CrossRef]

79. Khalil, S.; Belitski, M. Dynamic capabilities for firm performance under the information technology governance framework. Eur. Bus. Rev. 2020, 32, 129-157. [CrossRef]

80. Del Giudice, M.; Maggioni, V. Managerial practices and operative directions of knowledge management within inter-firm networks: A global view. J. Knowl. Manag. 2014, 18, 841-846. [CrossRef]

81. Shahzad, M.; Qu, Y.; Zafar, A.U.; Rehman, S.U.; Islam, T. Exploring the influence of knowledge management process on corporate sustainable performance through green innovation. J. Knowl. Manag. 2020, 24, 2079-2106.

82. Wiklund, J.; Shepherd, D. Knowledge-based resources, entrepreneurial orientation, and the performance of small and mediumsized businesses. Strateg. Manag. J. 2003, 24, 1307-1314. [CrossRef]

83. Farzaneh, M.; Ghasemzadeh, P.; Nazari, J.A.; Mehralian, G. Contributory role of dynamic capabilities in the relationship between organizational learning and innovation performance. Eur. J. Innov. Manag. 2020, 24, 655-676.

84. Sparrow, P.R. Reappraising psychological contracting: Lessons for the field of human-resource development from cross-cultural and occupational psychology research. Int. Stud. Manag. Organ. 1998, 28, 30-63.

85. Mokhtarzadeh, N.G.; Mahdiraji, H.A.; Jafarpanah, I.; Jafari-Sadeghi, V.; Cardinali, S. Investigating the impact of networking capability on firm innovation performance: Using the resource-action-performance framework. J. Intellect. Cap. 2020, 21, 1009-1034.

86. Jilani, M.M.A.K.; Fan, L.; Islam, M.T.; Uddin, M. The influence of knowledge sharing on sustainable performance: A moderated mediation study. Sustainability 2020, 12, 908. [CrossRef]

87. Chang, Y.-Y.; Chen, M.-H. Creative entrepreneurs' creativity, opportunity recognition, and career success: Is resource availability a double-edged sword? Eur. Manag. J. 2020, 38, 750-762. [CrossRef] 
88. Kuckertz, A.; Kollmann, T.; Krell, P.; Stöckmann, C. Understanding, differentiating, and measuring opportunity recognition and opportunity exploitation. Int. J. Entrep. Behav. Res. 2017, 23, 78-97.

89. Falahat, M.; Ramayah, T.; Soto-Acosta, P.; Lee, Y.-Y. SMEs internationalization: The role of product innovation, market intelligence, pricing and marketing communication capabilities as drivers of SMEs' international performance. Technol. Forecast. Soc. Change 2020, 152, 119908. [CrossRef]

90. Sanz-Velasco, S.A. Opportunity development as a learning process for entrepreneurs. Int. J. Entrep. Behav. Res. 2006, 12, 251-271. [CrossRef]

91. Ferreira, J.; Coelho, A.; Moutinho, L. Dynamic capabilities, creativity and innovation capability and their impact on competitive advantage and firm performance: The moderating role of entrepreneurial orientation. Technovation 2020, 92, 102061.

92. Schoemaker, P.J.; Heaton, S.; Teece, D. Innovation, dynamic capabilities, and leadership. Calif. Manag. Rev. 2018, 61, 15-42. [CrossRef]

93. Creswell, J.W.; Plano Clark, V.; Gutmann, M.L.; Hanson, W.E. An expanded typology for classifying mixed methods research into designs. In Handbook of Mixed Methods in Social and Behavioral Research; Tashakkori, A., Teddlie, C., Eds.; Sage North America: Irvine, CA, USA, 2003; pp. 209-240.

94. Bryman, A. Barriers to integrating quantitative and qualitative research. J. Mix. Methods Res. 2007, 1, 8-22. [CrossRef]

95. Brislin, R.W. Back-translation for cross-cultural research. J. Cross-Cult. Psychol. 1970, 1, 185-216. [CrossRef]

96. Kotrlik, J.; Higgins, C. Organizational research: Determining appropriate sample size in survey research appropriate sample size in survey research. Inf. Technol. Learn. Perform. J. 2001, 19, 43.

97. Hair, J.F.; Ringle, C.M.; Sarstedt, M. PLS-SEM: Indeed a silver bullet. J. Mark. Theory Pract. 2011, 19, 139-152. [CrossRef]

98. Hsu, M.-H.; Ju, T.L.; Yen, C.-H.; Chang, C.-M. Knowledge sharing behavior in virtual communities: The relationship between trust, self-efficacy, and outcome expectations. Int. J. Hum.-Comput. Stud. 2007, 65, 153-169. [CrossRef]

99. Davenport, T.H.; Prusak, L. Working Knowledge: How Organizations Manage What They Know; Harvard Business Press: Boston, MA, USA, 1998.

100. Hurley, R.F.; Hult, G.T.M. Innovation, market orientation, and organizational learning: An integration and empirical examination. J. Mark. 1998, 62, 42-54. [CrossRef]

101. Atuahene-Gima, K. Resolving the capability-rigidity paradox in new product innovation. J. Mark. 2005, 69, 61-83. [CrossRef]

102. Colbert, A.E.; Kristof-Brown, A.L.; Bradley, B.H.; Barrick, M.R. CEO transformational leadership: The role of goal importance congruence in top management teams. Acad. Manag. J. 2008, 51, 81-96. [CrossRef]

103. García-Morales, V.J.; Lloréns-Montes, F.J.; Verdú-Jover, A.J. The effects of transformational leadership on organizational performance through knowledge and innovation. Br. J. Manag. 2008, 19, 299-319. [CrossRef]

104. Alghazi, S.S.; Kamsin, A.; Almaiah, M.A.; Wong, S.Y.; Shuib, L. For Sustainable Application of Mobile Learning: An Extended UTAUT Model to Examine the Effect of Technical Factors on the Usage of Mobile Devices as a Learning Tool. Sustainability 2021, 13, 1856. [CrossRef]

105. Rahman, I.A.; Memon, A.H.; Aziz, A.A.A.; Abdullah, N.H. Modeling causes of cost overrun in large construction projects with partial least square-SEM approach: Contractor's perspective. Res. J. Appl. Sci. Eng. Technol. 2013, 5, 1963-1972. [CrossRef]

106. Nave, A.; Franco, M. University-Firm cooperation as a way to promote sustainability practices: A sustainable entrepreneurship perspective. J. Clean. Prod. 2019, 230, 1188-1196. [CrossRef]

107. Kusurkar, R.A.; Croiset, G.; Ten Cate, O.T.J. Twelve tips to stimulate intrinsic motivation in students through autonomy-supportive classroom teaching derived from self-determination theory. Med. Teach. 2011, 33, 978-982. [CrossRef] [PubMed]

108. Hair Jr, J.F.; Sarstedt, M.; Hopkins, L.; Kuppelwieser, V.G. Partial least squares structural equation modeling (PLS-SEM): An emerging tool in business research. Eur. Bus. Rev. 2014, 26, 106-121. [CrossRef]

109. Ab Hamid, M.; Sami, W.; Sidek, M.M. Discriminant validity assessment: Use of Fornell \& Larcker criterion versus HTMT criterion. In Proceedings of the Journal of Physics: Conference Series, Kuantan, Malaysia, 8-10 August 2017; p. 012163.

110. Henseler, J.; Hubona, G.; Ray, P.A. Using PLS path modeling in new technology research: Updated guidelines. Industrial management $\mathcal{E}$ data systems 2016, 116, 2-20.

111. Harman, H.H. Modern Factor Analysis; University of Chicago Press: Chicago, IL, USA, 1976.

112. Aiken, L.S.; West, S.G.; Reno, R.R. Multiple Regression: Testing and Interpreting Interactions; Sage: London, UK; New Delhi, India, 1991.

113. Fornell, C.; Larcker, D.F. Structural Equation Models with Unobservable Variables and Measurement Error: Algebra and Statistics; Sage Publications Sage CA: Los Angeles, CA, USA, 1981.

114. McNeish, D.; An, J.; Hancock, G.R. The thorny relation between measurement quality and fit index cutoffs in latent variable models. J. Personal. Assess. 2018, 100, 43-52. [CrossRef] [PubMed]

115. Walker, D.A. JMASM19: A SPSS matrix for determining effect sizes from three categories: $\mathrm{R}$ and functions of $\mathrm{r}$, differences between proportions, and standardized differences between means. J. Mod. Appl. Stat. Methods 2005, 4, 30. [CrossRef]

116. Sunny, S.A.; Shu, C. Investments, incentives, and innovation: Geographical clustering dynamics as drivers of sustainable entrepreneurship. Small Bus. Econ. 2019, 52, 905-927.

117. Henseler, J.; Fassott, G. Testing moderating effects in PLS path models: An illustration of available procedures. In Handbook of Partial Least Squares; Springer: Berlin/Heidelberg, Germany, 2010; pp. 713-735. 
118. Shu, H.; Fei, W.; Chen, C. Knowledge Sharing, Absorptive Capacity and Innovation Capability: An Empirical Study of Taiwanese Knowledge-Intensive Industries. J. Inf. Sci. 2007, 33, 340-359.

119. Jantunen, A.; Puumalainen, K.; Saarenketo, S.; Kyläheiko, K. Entrepreneurial orientation, dynamic capabilities and international performance. J. Int. Entrep. 2005, 3, 223-243.

120. Leal-Rodríguez, A.L.; Ariza-Montes, J.A.; Roldán, J.L.; Leal-Millán, A.G. Absorptive capacity, innovation and cultural barriers: A conditional mediation model. J. Bus. Res. 2014, 67, 763-768. [CrossRef]

121. Tseng, S.-M.; Lee, P.-S. The effect of knowledge management capability and dynamic capability on organizational performance. J. Enterp. Inf. Manag. 2014, 27, 158-179. [CrossRef]

122. Johnson, $\mathrm{H}$. The moderating effects of dynamic capability on radical innovation and incremental innovation teams in the global pharmaceutical biotechnology industry. J. Innov. Manag. 2020, 8, 51-83. [CrossRef]

123. Ferreira, J.; Cardim, S.; Coelho, A. Dynamic capabilities and mediating effects of innovation on the competitive advantage and firm's performance: The moderating role of organizational learning capability. J. Knowl. Econ. 2021, 12, 620-644.

124. Beltramino, N.S.; García-Perez-de-Lema, D.; Valdez-Juárez, L.E. The structural capital, the innovation and the performance of the industrial SMES. J. Intellect. Cap. 2020, 21, 913-945.

125. Torabi, F.; El-Den, J. The impact of knowledge management on organizational productivity: A case study on Koosar Bank of Iran. Procedia Comput. Sci. 2017, 124, 300-310. [CrossRef]

126. Marques, C.S.; Ferreira, J. SME innovative capacity, competitive advantage and performance in a'traditional'industrial region of Portugal. J. Technol. Manag. Innov. 2009, 4, 53-68. [CrossRef]

127. Bamel, U.K.; Bamel, N. Organizational resources, KM process capability and strategic flexibility: A dynamic resource-capability perspective. J. Knowl. Manag. 2018, 22, 1555-1572. [CrossRef]

128. Pezeshkan, A.; Smith, A.; Fainshmidt, S.; Sedeh, A.A. National business systems and firm innovation: A study of developing economies. J. Bus. Res. 2016, 69, 5413-5418. [CrossRef]

129. Pezeshkan, A.; Fainshmidt, S.; Nair, A.; Frazier, M.L.; Markowski, E. An empirical assessment of the dynamic capabilitiesperformance relationship. J. Bus. Res. 2016, 69, 2950-2956.

130. Xie, G.-H.; Wang, L.-P.; Lee, B.-F. Understanding the Impact of Social Capital on Entrepreneurship Performance: The Moderation Effects of Opportunity Recognition and Operational Competency. Front. Psychol. 2021, 12, 2026. [CrossRef] [PubMed]

131. Feng, T.; Cai, D.; Wang, D.; Zhang, X. Environmental management systems and financial performance: The joint effect of switching cost and competitive intensity. J. Clean. Prod. 2016, 113, 781-791.

132. Cheng, H.; Chen, C.; Wu, S.; Mirza, Z.A.; Liu, Z. Emergy evaluation of cropping, poultry rearing, and fish raising systems in the drawdown zone of Three Gorges Reservoir of China. J. Clean. Prod. 2017, 144, 559-571. [CrossRef]

133. Middermann, L.H.; Kratzer, J.; Perner, S. The impact of environmental risk exposure on the determinants of sustainable entrepreneurship. Sustainability 2020, 12, 1534. [CrossRef] 